\title{
Inflation? It's Import Prices and the Labor Share!
}

\author{
Lance Taylor and Nelson H. Barbosa-Filho ${ }^{\dagger}$
}

\author{
Working Paper No. 145
}

January $2^{\text {th }}, 2021$

\begin{abstract}
Recognizing that inflation of the value of output and its costs of production must be equal, we focus on a cost-based macroeconomic structuralist approach in contrast to micro-oriented monetarist analysis. For decades the import and profit shares of cost have risen, while the wage share has declined to around 50\% with money wage increases lagging the sum of growth rates of prices and productivity. Conflicting claims to income are the underlying source of inflationary pressure.

Inflation affects income (labor's spending power) and wealth. Monetarist theory around 1900 concentrated on the latter (Bryan and the "Cross of Gold)" leading to the standard Laffer curve. It was replaced by the Friedman-Phelps model which has incorrect dynamics (labor payments do not fall during an expansion - they go up). Samuelson and Solow introduced a version of the Phillips curve that violates macroeconomic accounting. Rational expectations replaced Friedman but was immediately falsified by output drops after the Volcker shock treatment around 1980. There

${ }^{\dagger}$ Arnhold Professor Emeritus, New School for Social Research and Getulio Vargas Foundation, Brazil, respectively. Support from INET and comments from Thomas Ferguson are gratefully acknowledged.
\end{abstract}


followed a complicated transition from rational expectations to inflation targeting, anchored by economists' misunderstanding of the physical meaning of ergodicity and ontological blindness. It did not help that the real balance effect is irrelevant because money makes up a small part of wealth. Rather than issuing veiled threats of disaster if its policy advice is not followed, the Fed now announces inflation targets which it cannot meet.

Contemporary structuralist theory suggests that conflicting income claims set the inflation rate. Firms can mark up costs but workers have latent bargaining power over the labor share that they can exercise. Import costs and policy repercussions complicate the picture, but a simple vector error correction model and visual analysis suggest that money wages would have to grow one percentage point faster than prices plus productivity for several years if the Fed is to meet a three percent inflation target.

The results pose a Biden policy trilemma: (i) the only path toward a more egalitarian size distribution of income is through a rising labor share (money wage growth exceeds price plus productivity growth), (ii) which would provoke faster inflation with feedback to rising interest rates, and (iii) the resulting asset price deflation likely facing political resistance from Wall Street and affluent households.

\section{https://doi.org/10.36687/inetwp145}

JEL codes: E31, E32

Key words: Cost-based inflation, structuralist inflation, conflicting claims 
Inflation, after decades, is once again coming to the forefront of US economic policy discussion. One reason is surely the authorization of the $\$ 3$ trillion CARES act and preceding legislation which allowed a massive expansion (some recently revoked by the Treasury and then subject to frenzied debate in Congress) of the Federal Reserve balance sheet to support unemployment relief through various channels. The Fed subsequently promised to allow inflation, over which it has no direct control, to exceed its target rate of two percent per year before imposing contractionary policy.

Consumer price index (CPI) inflation is at less than two percent per year and the Fed funds interest rate near half-a-percent. If the wage share of gross domestic income remains stable, the Fed cannot push the inflation rate above the target, for reasons presented below. In public pronouncements, neither Jerome Powell, the current Fed Governor, nor his associates would ever admit to that fact.

Every economy has its own inflation, with details depending on local class relations, structure of production, and institutions. There are many inflation theories, each incomplete. In this paper we attempt to outline some through the turn of this century for the USA and pursue implications for policy. The bottom line is that changes of the labor share of output are a main domestic driver for price inflation. Money wage repression, in particular, holds price increases in check. Import costs, in part responding to exchange rate changes, also play an important role.

In what follows we quickly review American inflation history, and go over a set of theories, ordered from the least to most relevant (monetarist to structuralist), and from high conventional acceptance to low. Wage repression with low inflation under conflicting income claims is central to recent US experience. Econometric modeling is used to assess the Federal Reserve's chances of reaching a higher inflation target. They are not good. A technical appendix presents a model explaining why.

Three initial observations lead into the discussion.

Inflation involves ongoing exponential growth of prices of goods and services and their associated costs per unit output, mostly wages but also prices of other essential inputs into final production, e.g. food and raw materials. It is intrinsically a dynamic process. Growth rates of prices and wages can range between a few and a few thousand percent per year. Societies' tolerances for inflation vary greatly across time and space.

Exponentially growing prices and costs can serve as a buffer or escape valve for unresolved social conflict. They mediate conflicting claims for wealth and income between creditors and debtors, capitalists and workers, food or energy producers and consumers. Unless conflict is repressed or resolved, inflation is likely to march on. Tools are available to make it stop, but distributional and employment consequences can be grim.

Inflation is a dynamical macroeconomic process. Structurally, it must be analyzed taking into account the demand side of the economy (gross domestic product or GDP) and the cost side 
including output and labor payments (gross domestic income or GDI). Subject to errors and omissions, GDP = GDI, a macro level constraint on the system. Monetarism is basically microeconomic. A change in some variable, say employment, is supposed to affect another, say the price level. This textbook supply-and-demand orientation elides macroeconomics. It is the reason why monetarist theory so frequently fails in practice.

\section{Cost-based structuralist US inflation}

We begin with a cost-based structuralist review of US inflation history, go on to standard monetarist analysis, and then structuralist inflation theory applied to the present situation.

\section{Decomposition of costs}

Compared to many country experiences over the years, the history in America is rather bland, perhaps due to the central role of finance in the nation's political economy. Despite its plodding course, American experience is of interest because it animates several versions of orthodox theory, ${ }^{1}$ The data show that there were quarterly jumps of the consumer price index (CPI) inflation rate toward twenty percent per year during and after both World Wars. They soon subsided. Figure 1 illustrates the process post-1947. As opposed to conventional treatments such as the Laffer curve (see below) it takes a "left" or structuralist stance by presenting inflation from the perspective of cost, not price. Components of cost are imports, payments to labor (including "supplements" for insurance, pensions, etc., paid by employers), taxes, and gross capital income (including payments to proprietors, etc.). Indexes are on a log scale, with cost per unit output at 100 in 1960. In the diagram, the labor share has consistently been pressed "from below" by rising imports and "from above" by increasing business taxes and gross profits. ${ }^{2}$ Figure 2 helps fill in the details, showing a relative decomposition of the costs of total supply.

\footnotetext{
${ }^{1}$ There are unnerving parallels with particle physics. No new experimental evidence since the 1970s pushed brilliant minds into constructing abstract, mathematical theory which does not generate practical insight (Hossenfelder, 2018). The same can be said of mainstream macro theory and econometrics.

${ }^{2}$ Net interest and dividend payments from US business are over a trillion dollars per year, and certainly can be passed into prices - an "effect" often stressed by the Texas Congressman Wright Patman when he criticized the Fed.
} 
Figure 1: Log of the cost of total supply. Note how labor cost is squeezed "from below" by rising imports and "from above" by profits.

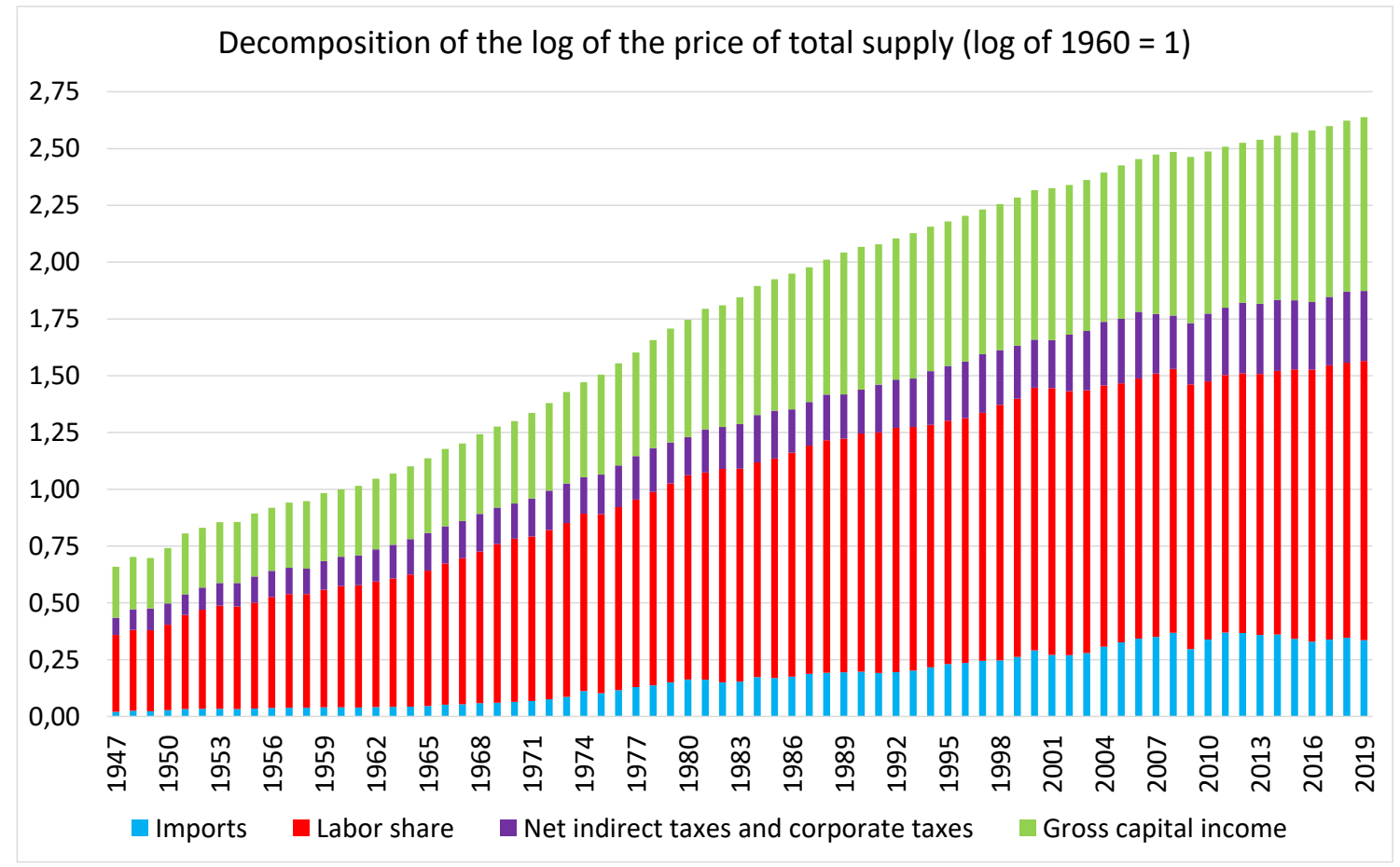

Macroeconomic implications

A rule of thumb is that the macroeconomic system is visibly sensitive to shocks or perturbations on the order of one percent of GDP. Changes in capital income and imports in Figure 2 are larger than that.

One implication is that the shifts may have cut into aggregate demand. Imports net of exports are "saved" in the sense that they are financed by lending from saving abroad. The saving rate from profits is far higher than the rate from wages so overall saving must have risen, reducing consumption demand. ${ }^{3}$

\footnotetext{
${ }^{3}$ A potential offset is higher investment due to more profits - a possibility pursued in the discussion of MarxGoodwin cycles below.
} 
Figure 2: Composition of total supply cost

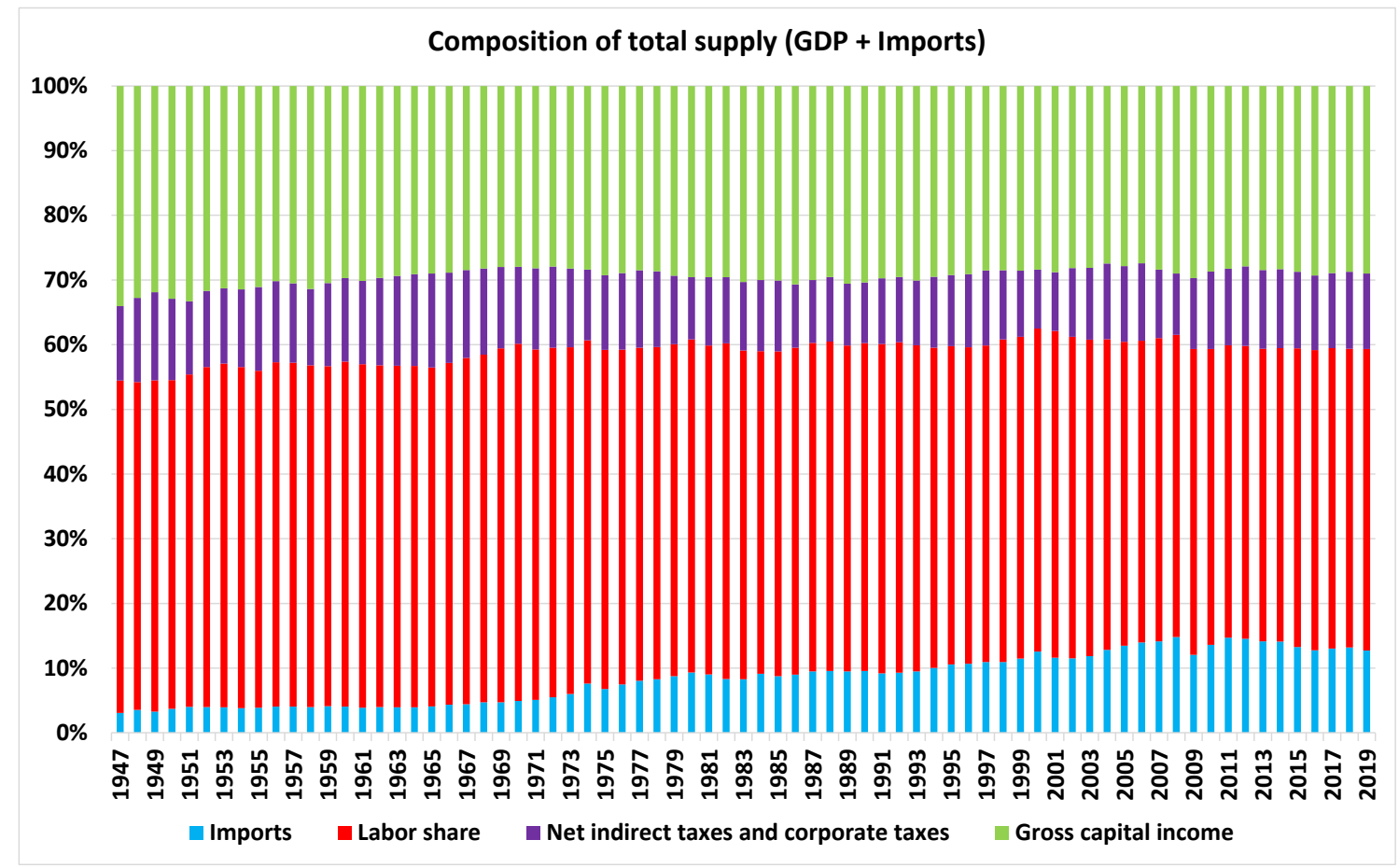

Structural contributing factors to pressure on real wages were offshoring of productive activity through growth of international supply chains and, after 1990, a double-digit shift in total employment from high wage/high productivity sectors to those with low levels of both metrics (Taylor with Ömer, 2020). Both changes increased labor productivity overall and cut into the wage share which equals the real wage divided by productivity. (Reshoring would presumably reduce US productivity, raising the share).

In any case, after a relatively stable period there was an upswing in import costs beginning in the 1960s, including two oil price shocks and a grain price spike in the 1970s. Later, the labor share was hit by the commodity super-cycle (roughly 2000-2015) which pushed up import costs. The profit share stabilized and began to go up as the labor share started a long-term downward trend after 1970 .

\section{Federal Reserve shock}

After 1960 there was a run-up to stagflation (Figure 3). The CPI rate rose to around 13\%, pulling the velocity of money circulation up with it. ${ }^{4}$ The policy response around 1980 was monetarist shock therapy administered by the Federal Reserve. The International Monetary Fund has a wellestablished protocol for attacking inflation in developing economies - apply contractionary monetary policy and suppress growth of money wages. The Fed adopted the Fund's game plan, taking advantage of the fact that wage growth had already slowed before it swung into action.

${ }^{4}$ We define velocity of circulation as the ratio of nominal GDP to the stock of Money of Zero Maturity (MZM) in figure 3 . 
The intervention knocked inflation down to four percent by 1990. Thereafter it drifted further downward to something between one or two percent today. High interest rates drew capital inflows and set off anti-inflationary dollar appreciation. The consequent trade deficit was finally reduced as a result of dollar devaluation in connection with the 1985 Plaza Accord (Taylor 2020). Also note that the inflation rate is cyclical or at least rhythmic, rising during an output upswing and dropping off with recession in line with the "Marx-Goodwin" (1967) cycle and Barbosa-Taylor (2006) among others discussed below.

The fact that per unit costs must track along with prices is illustrated in Figure 4 using the GDP deflator as the price index because it reflects costs of production better than the CPI. The relevant comparison is between money wage inflation and the sum of price inflation and the rate of productivity growth since the latter reduces costs. The diagram shows that after the 1970s wages lagged prices and productivity, leading to a decrease in the labor share. Over five decades, the share fell by about five percentage points (Taylor with Ömer, 2020).

\section{Figure 3: CPI Inflation Rate vs. Velocity = GDP/MZM (YoY)}

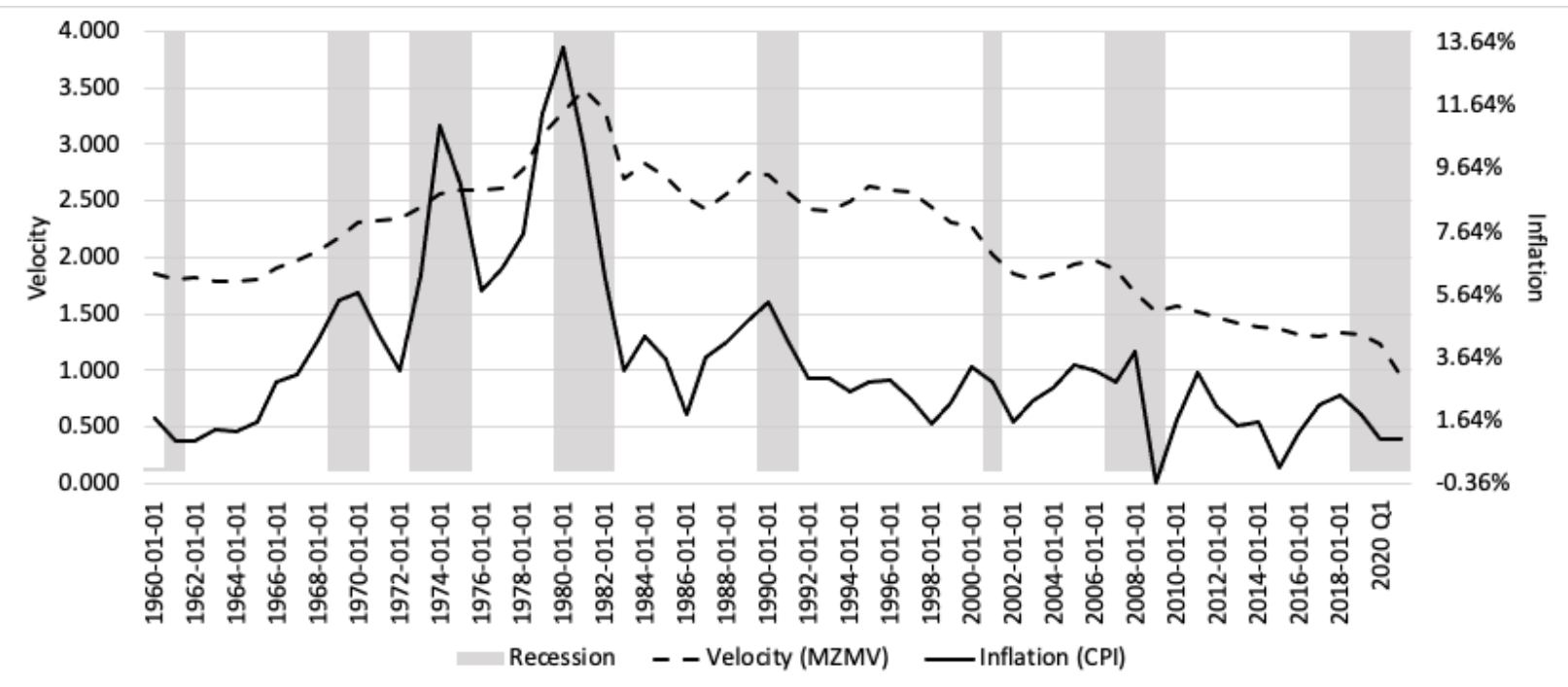

\section{Monetarist inflation theories}

There is no dearth of monetarist inflation discourse. Here we simply try to summarize a few central themes.

\section{Monetarism I (The Cross of Gold, etc.)}

Monetarism carries its own distributional implications. If interest rates are controlled (the current catch phrase is "financial repression"), inflation will harm creditors and benefit debtors. In 1896 when William Jennings Bryan gave his famous speech at the Democratic National Convention, deflation at around -2\% per year was underway, devastating the net worth of his Populist farmer 
supporters. He wanted to switch from a gold to silver standard for the dollar, while New York bankers preferred gold to pacify foreign lenders. For reasons not fully understood (perhaps including Alaskan gold discoveries) deflation switched to inflation at $+2 \%$ not long after Bryan proclaimed that Middle Western humankind should not be crucified on a cross of gold.

Figure 4: Money wage growth (w_hat) vs. GDP deflator growth plus productivity growth (deflator_hat+xi_hat) and the labor share including "supplements"

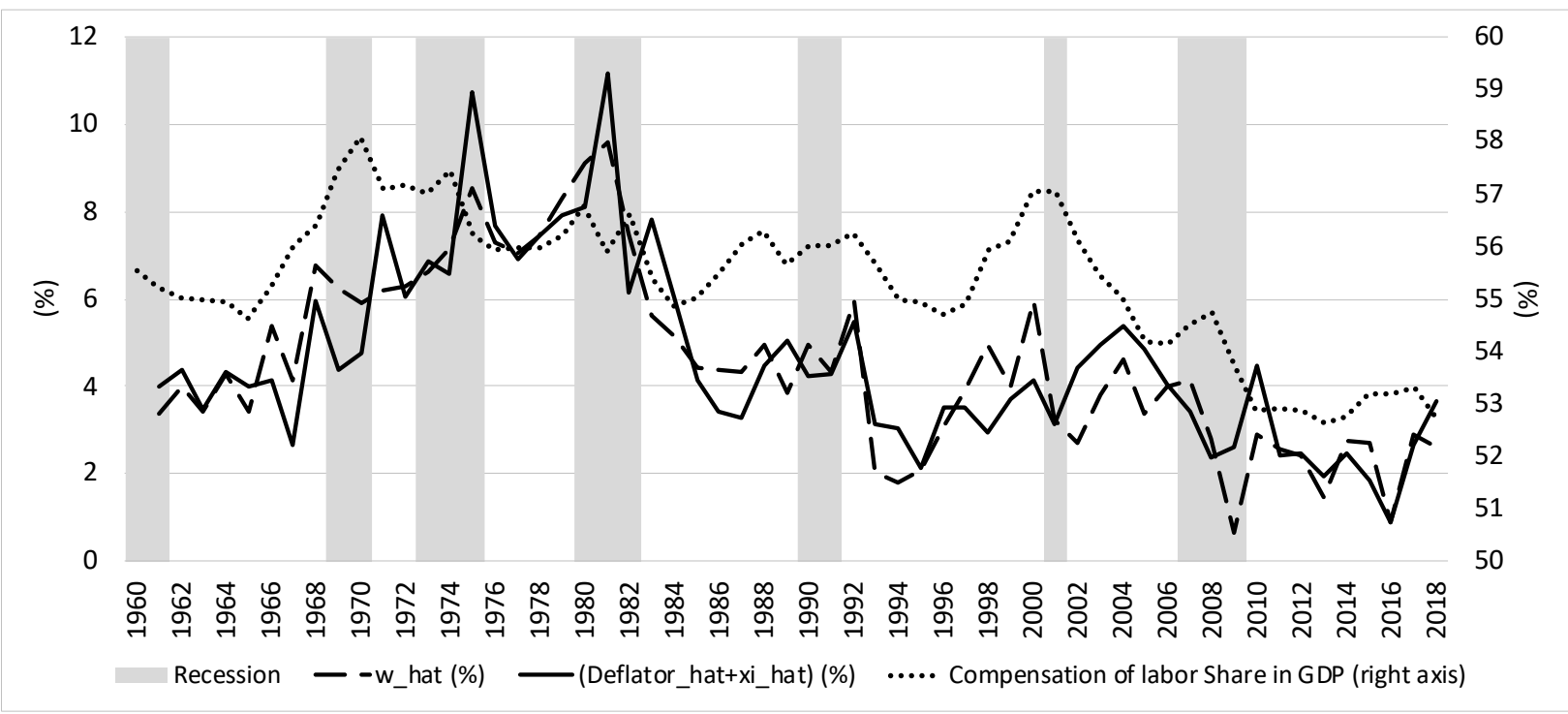

Wall Street held strong views about how inflation could be kept in check by tying the dollar to a stable supply of gold. There were financial panics in 1893 and 1907. In both, the New York banker J. P. Morgan organized private rescue operations which successfully kept the USA on the gold standard. A century later, Treasury Secretary Robert Rubin created a "strong dollar" policy like Morgan's.

The effect of trending prices of goods and services on wealth exemplifies the "inflation tax" on the purchasing power of money (the real balance effect discussed below is another example). On the side of payments if prices rise more rapidly than wages, then workers have to cut back on consumption. This squeeze is called “forced saving," It can be countered by households' running up debt, as before the Great Recession.

\section{Monetarism II (hyperinflation)}

Three institutional factors contribute to hyperinflation. One is enhanced bargaining power on the part of labor, for example in Germany with both Communist and Christian unions active in the wake of the Versailles Treaty. Second, business has power to mark-up rising labor costs. Finally, during hyperinflation the banking authorities create money to meet demand. Although remote from American experience (so far) hyperinflation illustrates monetarist theory's logic. Influential US papers from the 1960s and 1970s look plodding by comparison. 
Suppose that the money supply or $M$ is determined by factors such as stocks of precious metals or reserve requirements in the banking system. If $P$ is the overall price index and $X$ is output, the "velocity" $V$ of money is set by a tautology called the "equation of exchange,"

$$
M V=P X
$$

or Money $\times$ Velocity $=$ Value of Output.

With $M$ fixed, equation (1) serves as a demand function for money. As the ratio of nominal output to money, velocity measures the number of times per year that the money stock turns over to facilitate economic activity. In rich economies it is typically a low positive number as in Figure $3 .^{5}$ Velocity tends to increase when money's real purchasing power $M / P$ drops more rapidly. The rate of inflation can be written as $\widehat{P}=\dot{P} / P=(d P / d t) / P$. With $V(\widehat{P})$ as an increasing function of $\widehat{P}$ we get a price level that diverges toward infinity. Suppose that the money supply is growing at some exponential rate $\widehat{M}$ in a growth rate version of (1),

$$
\widehat{M}+v(d \hat{P} / d t)=\hat{P}+\hat{X}
$$

or

$$
d \hat{P} / d t=(1 / v)(\hat{P}+\hat{X}-\widehat{M})
$$

with coefficient $v>0$.

Because velocity goes up with $\widehat{P}$, the change in inflation $d \hat{P} / d t$ becomes an increasing function of the inflation rate itself, a recipe from dynamic instability. This phenomenon is always observed in economies with hyperinflation. ${ }^{6}$

Unlike its cost-based left counterpart in Figures 1 and 2, the original Laffer curve says that if the growth rate of money is suddenly accelerated from zero, velocity growth will go up by a lesser amount. Hence real revenue $M / P$ from money creation will rise. In the jargon, this "seigniorage" will increase to some maximum and then tail off to zero. Laffer just draws a cartoon of this process.

When exponential inflation is finally stopped, usually there is a surge in consumption as the inflation tax and forced saving come to an end, raising demand.

\section{Monetarism III (Friedman-Phelps)}

Although equation (2) was popular with Chicago Boy developing country money doctors, US economists backed away from it, preferring to work with (1) setting the value of output proportional to the money supply. A jump in $M$ will now eventually be met by a proportional

\footnotetext{
${ }^{5}$ MZM (money of zero maturity) is "broad" money. It measures the supply of financial assets redeemable at par on demand, including CDs and money market funds.

${ }^{6}$ Economists who lived through the experience like to boast about how flight from money in their economies during hyperinflation drove velocity up to 50 or 80 or whatever.
} 
increase in the price level as in an influential model proposed by Friedman (1968) and Phelps (1968). The key is a hardy perennial known as the real balance effect. With causality running from right to left, the equation of exchange can be stated as

$$
X=V(M / P)
$$

Presumably by reducing interest rates, an increase in the monetary "real balance" $M / P$ is supposed to drive up demand for output. In practice it is interesting to examine markets for output and labor separately. In a fancier version of (3) demand minus supply ("excess demand") for output must equal zero in equilibrium,

$$
V(M / P)-f^{s}(w / P)=0
$$

with $w$ as the money wage, Along the supply schedule $f^{S}(w / P)$, a lower real wage $w / P$ is supposed to induce firms to hire more workers and raise output. The price level $P$ adjusts to clear the market. The higher price reduces real balance and aggregate demand while cutting the real wage and boosting supply.

In the labor market, workers are postulated to be somewhat dull. They make decisions about how much labor (scaled to output) to supply on the basis of an expected price level $P^{e}$,

$$
f^{s}(w / P)-g^{s}\left(w / P^{e}\right)=0
$$

The money wage is the short-run adjusting variable in (5). Over time, the workers' expected price is supposed to move slowly toward the current price level $P$.

Figure 5 illustrates the model in terms of growth rates $\widehat{w}$ and $\widehat{P}$ (details in Taylor, 2004). An initial macro equilibrium has $\widehat{w}=\widehat{P}=0$ and a constant real wage. If $M$ increases, shifting the "Output" schedule to the right, $\hat{P}$ is supposed to go up rapidly (or "jump") to restore goods market balance. In the labor market, workers with their slowly adjusting expected price initially offer to work more to meet higher demand. But $P^{e}$ drifts upward to meet the higher $P$ as the system converges to its initial output and real wage with higher nominal price and wage levels growing at a common and faster rate of inflation.

Fifty years later it is hard to see why this contraption generated an uproar. The only way you can get an ongoing inflation is to accelerate growth of the money supply in traditional monetarist fashion. Friedman's assertion that "inflation is always and everywhere a monetary phenomenon" is just a result of too much money printing for too little income growth in a simple macro model. Phelps agreed, receiving the 2006 Nobel prize in "economic science." Friedman already got it in 1976.

The famous real balance effect, much touted by neoclassically inclined economists, is irrelevant today. A broad monetary aggregate like MZM is around $\$ 20$ trillion, or $16 \%$ of household wealth. The propensity to consume from wealth is around four percent, so a visible decrease in real balances will have a negligible impact on aggregate demand. 
Figure 5: Macroeconomic balance in the Friedman-Phelps model

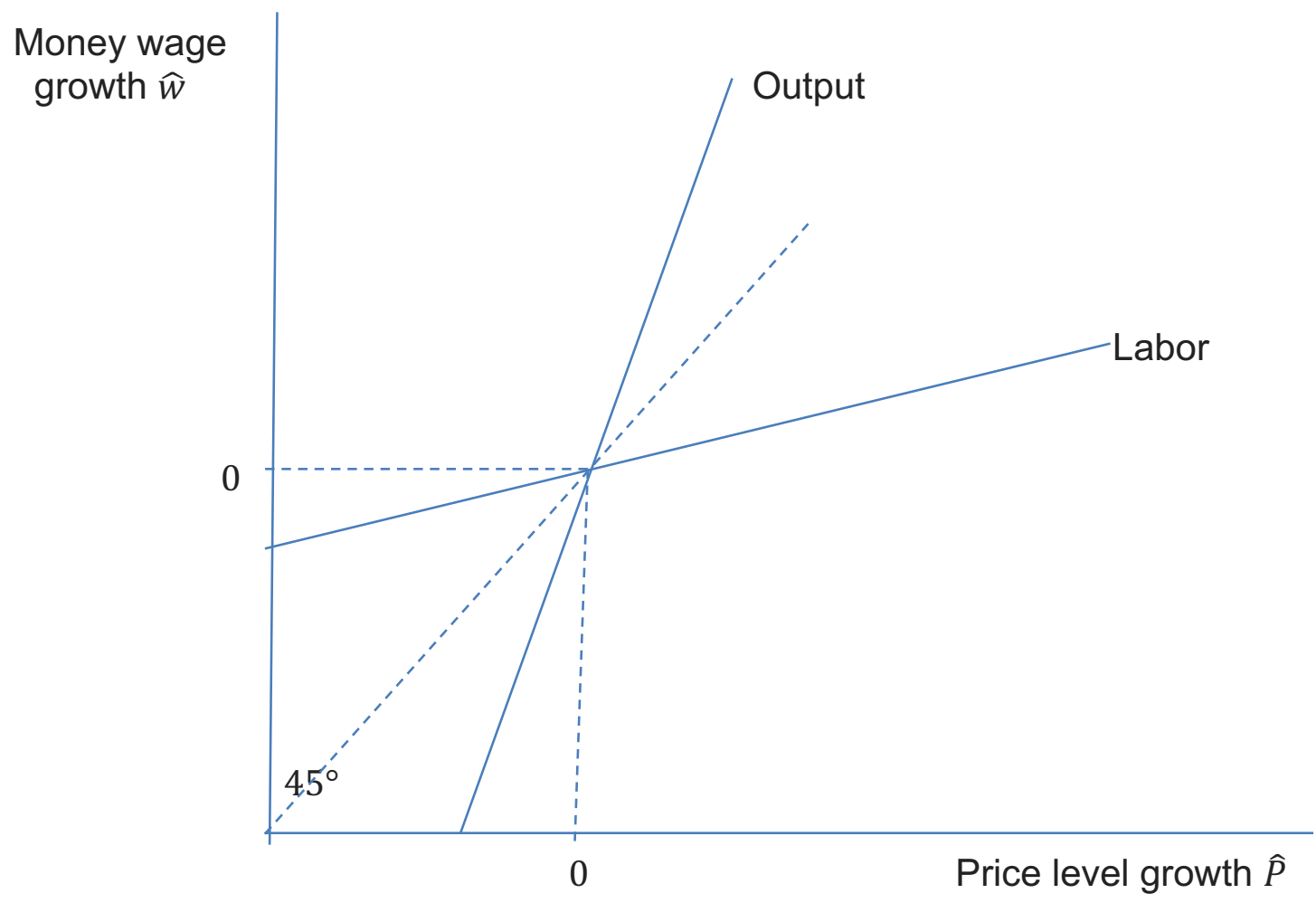

Finally, Figure 2 shows that the model's dynamics is wrong. Empirically the labor share rises as the economy expands, and then tails off, just the reverse of what Friedman says. The saving grace, perhaps, is that imposing proper dynamics on the model's accounting leads naturally to structuralist inflation theory of a "Non-Accelerating-Price Rate of Unemployment" (NAPRU), which is not a stable parameter. 
Figure 6: Macroeconomic balance in the Lucas model

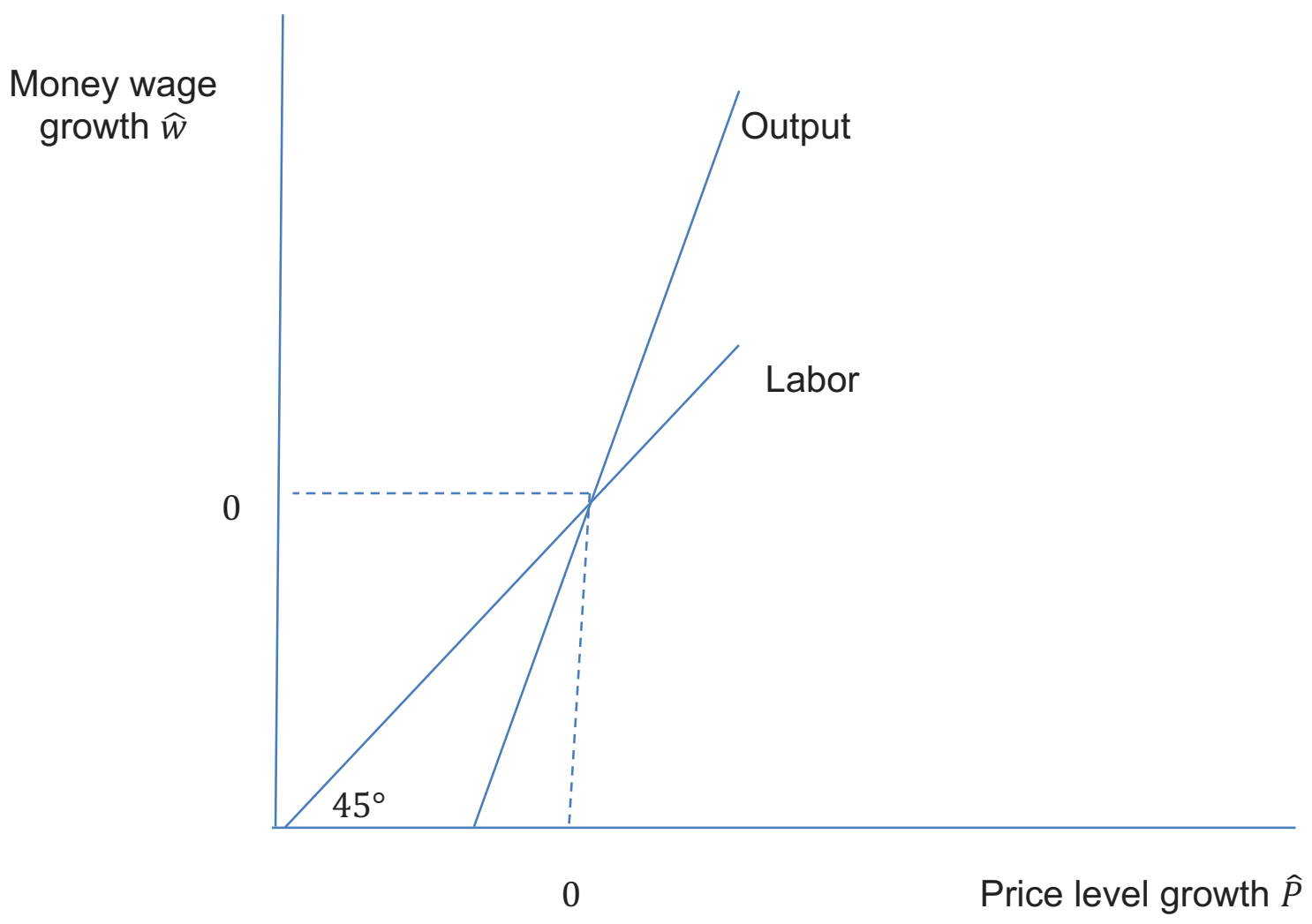

\section{Monetarism IV (Lucas new classical, rational expectations)}

The expected price $P^{e}$ was Friedman's undoing. Seizing upon expected inflation $\hat{P}^{e}$, Robert Lucas (1972) blew him from Hyde Park Chicago into retirement atop San Francisco's Russian Hill. His model can be illustrated as in Figure 6. Instead of slow wage adjustment growth expected price growth is supposed to jump rapidly to its full employment growth level ( $\hat{P}^{e}=$ $\widehat{P})$ when demand goes up. Wage growth jumps as well $(\widehat{W}=\widehat{P})$. Friedman's and Phelps's NAIRU comes back as a key concept, but with an important twist: if agents are rational and can gradually approximate the true model of how the economy works, they react immediately to any news about shocks and monetary policy, supposedly making it possible to reduce inflation with little or no loss of employment and output. The hypothesis of costless disinflation was quickly discredited by the Volcker shock of the late 1970s and 1980s, but it still haunts some academic departments based on a circular reasoning: if the policy did not work as expected, it was because the monetary commitment was not credible enough, making the original hypothesis impossible to refute. 
Despite apparent mathematical complexity, the New Classical models of Lucas and his acolytes are based on two basic assumptions. One is a tautology. The other is nonsense.

The tautological idea is more philosophical than mathematical: a rational agent does not make predictable mistakes. So, any mistake must have been because of a completely unforeseen error, a "white noise" in statistical jargon. This idea makes it possible to solve any model problems that depend on expectations (forward-looking behavior) in terms of the past behavior of the economy (backward-looking behavior), after one imposes assumptions about how the world works (preferences, technology, and resource constraints) on the data (Anderson 2008).

The nonsensical notion is that the "data generating process" of all economic and social phenomena is stable, so that anyone can estimate the true functioning of the economy from a long enough sample of observations of its key variables. In the jargon of statistical physics, in New Classical economics the economy is "ergodic", in the sense that by observing a time average of its statistical moments (mean, variance, skewness, etc.) anyone can gradually get close to the values of its true parameters. If this holds, uncertainty can be reduced to risk measurement of a known probability of distribution, in the kind of exercise done by Wall Street rocket scientists to price subprime loans prior to the Global Financial Crash of 2008.

Lucas's explanation of cycles as big monetary surprises quickly became another exhibit in the museum of implausible economic ideas (leading ultimately to the 1995 Nobel). US experience since the 1980s proved that disinflation is not costless, while the evolution of monetary policy showed that Central Banks target the rate of interest, not the money supply. It was therefore necessary to rewrite the monetarist approach to inflation in terms of a natural rate of interest instead of a natural rate of employment.

This maneuver had already been outlined at the end of the $19^{\text {th }}$ century by the Swedish economist Knut Wicksell. One hundred years later, New Keynesian economics reframed Wicksell's ideas in terms of intertemporal optimization by families, firms, and the government, creating the Dynamic Stochastic General Equilibrium (DSGE) models that dominated macroeconomic policy analysis until recently. Woodford (2003) is the prime example of a complicated and unrealistic model.

At any time, how are rational actors supposes to "know" $\hat{P}^{e}$ when all the information they have is about the current price level? Because the on-going change in $P$ is unobservable the model is ontologically challenged. Statistical techniques based on historical data can track a trending price index. But it is a variable observed with a lag subject to Keynes-Knight fundamental uncertainty. The tracking can always go wrong. Rational expectations in a non-ergodic world is ontological nonsense, but that did not stop a generation of academic economists from deploying ever more useless mathematics to try to describe what they were seeing. 
Ergodic is the key word. ${ }^{7}$ In applied physics, suppose that at one atmosphere of pressure you put one part ice at $0{ }^{\circ} \mathrm{C}$ into almost exactly 4 parts water at $20^{\circ} \mathrm{C}$. The water will cool to $0{ }^{\circ} \mathrm{C}$. This process is ergodic - you can do it over and over again with exactly the same result. In the jargon the "time average" of the results is the same as the "ensemble average." Many physical processes are experimentally ergodic in this sense. Outcomes in billiards with elastic balls are predictable but not ergodic, a far better simile for macroeconomics (assuming that there are no unforeseen crises).

Last century, sophisticated mathematics was invented to treat the evolution of each experiment as one member of the ensemble. The water will reliably cool each time but the details of molecular motion will be different. Econometricians took over this math to model one economy's inflation time series as a representing an ensemble (of what, a big range of other economies?), allowing the analysis of inflation as a mathematically tractable process. ${ }^{8}$

\section{Monetarism V (rational expectations to inflation targeting)}

With the failure of the Volcker shock to control money supply, the Fed gave up on Lucas and resumed setting interest rates in 1982 The transition was complicated, both historically and analytically, to say the least.

The obvious questions were: what should guide the short-run rate? In a trial-and-error process, the Fed first used the unemployment rate as a guide along the Samuelson-Solow lines discussed below. It boosted the Fed Funds rate when the observed rate of unemployment fell below a threshold. However, because of the structural changes in the US economy, the equilibrium rate of unemployment proved to be a moving target. The search was on for a better guide to monetary policy. The response was to look at inflation itself.

Central bank targeting of the rate of interest and letting the money supply fluctuate became a rule under which the authorities set the interest rate according to the deviation of expected inflation from a given target. The first mover was New Zealand in 1989 when it was running a 20\% inflation. It quickly became the Sherpa for monetary policy in both advanced and developing countries.

By February 1989, Fed Governor Alan Greenspan asserted that "No one can say precisely which level of resource utilization marks the dividing lines between accelerating and decelerating prices. However, the evidence - in the form of direct measures of prices and wages - is clear that we are now in the vicinity of that line." Then by the early 2000s, the Fed finally announced a formal inflation target of $2 \%$ per year, which it has been struggling to meet for the two decades since.

\footnotetext{
${ }^{7}$ The $19^{\text {th }}$ century German physicist Ludwig Boltzman invented it based on the Greek ergon or work. ${ }^{8}$ In the $20^{\text {th }}$ century, physics shifted to a stochastic approach to ergodicity. Economists followed obediently behind. Peters (2019) gives a helpful history. Descriptions of ergodicity in both deterministic and stochastic frameworks come to similar conclusions.
} 


\section{Monetarism VI (the contemporary model)}

The logic of inflation targeting is based on three stylized facts, which were later transformed into the "3-equation" model that permeates modern macroeconomics (equations appear below).

First, output depends on effective demand, which depends on the expected rate of interest. The higher the real rate of interest, the lower the effective demand, and therefore, output and employment. This relation is called the "IS" curve from Hicks's version of Keynes's General Theory.

Second, inflation depends on effective demand. The higher the level of economic activity, measured by capacity utilization, the rate of employment or other index of resource use, the higher the inflation. The idea is not new. In the $19^{\text {th }}$ century, Marx had already pointed out that the workers' bargaining power depends on the size of the reserve army of labor. Call the latter unemployment and one gets to the modern description of the conflict between labor and capital, where the rate of employment is an instrument to make the workers' wage claims coincide with what firms are willing to pay. This Phillips curve or "PC" links inflation to demand for real output. Like the IS curve, the Phillips curve is not necessarily stable. New Keynesian versions downplay sources of inflation other than real demand pressures. ${ }^{9}$

Third, the rate of interest set by central banks is a function of inflation. There is a monetary rule (MR) linking expected inflation to the rate of interest. The crucial point is that monetary authorities try to guide the interest rate to achieve stable inflation in the long run. The long run of monetary policy is defined through the central bank's communication. The authorities should explain why inflation deviates from target; what actions will be taken to make it converge; and how long it will take to get there. The Fed's latest suggestion that it may allow inflation to exceed two percent amounts to admitting it does not know why, what to do, and how long.

Like the IS and PC, the logic of the monetary rule emerged from the fact that central banks still set interest rates based on inflation expectation. Tracing back to Lucas, economists' professional rationale for targeting became intertemporal optimization by the central bank. The authorities guess what? - are supposed to set up a "true" DSGE model of the economy based on rational expectations and the ergodicity assumption!

Given the IS, PC and MR, we have three equations for three variables: effective demand, inflation and the rate of interest. The demand part is usually defined by the difference between effective output and potential output, which brings a fourth variable to the model. All the way until the global financial crisis of 2008, most mainstream macroeconomists lived happily believing that whatever demand shocks hit the economy, output would always return to its supply-driven trend, given by technology and preferences. However the real world insisted on

\footnotetext{
${ }^{9}$ Gordon (2011) gives an exhaustive history, emphasizing demand for output. See Carlin and Soskice (2005) for an orthodox graphical presentation.
} 
contradicting the model, causing the "secular stagnation" of the last decade. It is now admitted that demand shocks can have persistent or even permanent impacts on supply.

Despite the complexity of intertemporal optimization, the logic of the New Keynesian "3equation model" can be described through a simple system of four equations. Besides Athos, Porthos, and Aramis in the Three Musketeers, there is crucial fourth character in the plot.

Formally, the IS curve says that income $(y)$ is a function of the expected rate of interest $\left(r^{e}\right)$ :

$y=y_{A}-\gamma r^{e}+v_{d}$

where $y_{A}$ is the autonomous or "non-interest-rate sensitive" part of demand, $v_{d}$ represents demand shocks, and $\gamma>0$ so that an increase in the rate of interest lowers economic activity. For the record, Figure 7 shows how the interest rate trails the GDP deflator. Three aspects are relevant to policy.

One is Fed interest rate tracking. Another is that arbitrage relationships within the bond market force interest rates (the term structure) to follow inflation more or less closely.

The third dates back to the days of Alan Greenspan as Governor of the Fed (1987-2006). After the dot-com bubbles burst in 2000 he instituted a policy of holding rates down whenever asset prices, especially on the stock market, wobbled. In a process that economists call capitalization, a lower interest rate will tend to increase the net present value of an asset's returns over time, thus raising its market valuation (the financial press has recently been full of discussion of this phenomenon). Wall Street and rich households reap the gains. As discussed below, it will play a crucial role in policy formation.

Figure 7: Inflation vs. short-term Fed funds interest rate. Look at how closely the rate tracks the deflator.

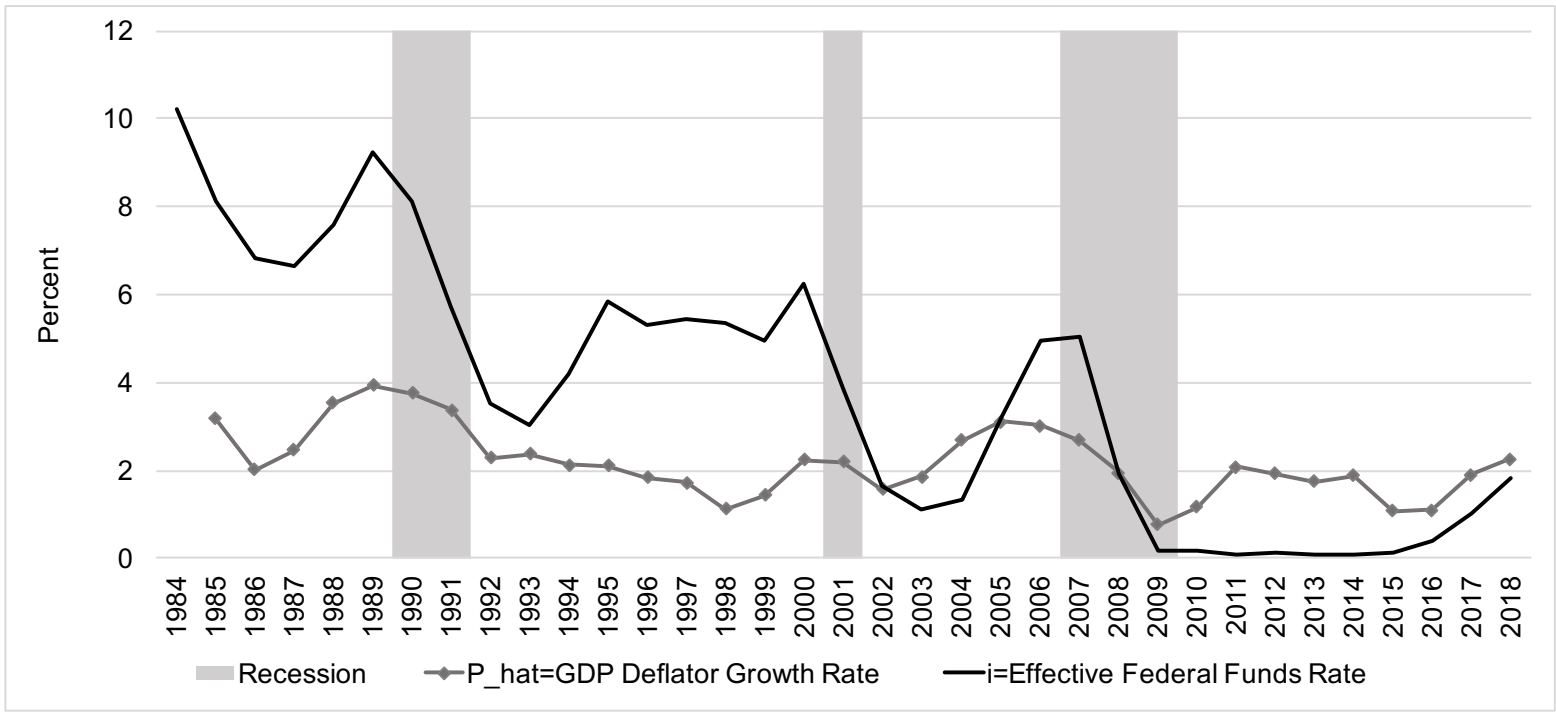




\section{The Phillips curve in practice}

According to the Phillips curve as usually stated, observed inflation $(\hat{P})$ depends on expected inflation $\left(\hat{P}^{e}\right)$ and the deviation of effective income from the potential output of the economy $\left(y^{*}\right)$.

$\widehat{P}=\hat{P}^{e}+\alpha\left(y-y^{*}\right)+v_{p}$

where $\alpha>0$ and $v_{p}$ represents price shocks. This equation exposes the fundamentally microeconomic aspect of monetarism. You change a quantity variable $(y)$ on the right-hand side, and the price on the left adjusts just as in the textbooks.

But inflation is essentially macroeconomic. Its analysis must be integrated with the KeynesStone-Meade national accounts. In stripped-down form, they state that

$$
P C+P D=\pi X+w b X+e P^{*} m X
$$

with $X$ as output, $C$ consumption, $D$ autonomous demand, $P$ the price level, $\pi$ the share of profits in gross domestic income (GDI), $w$ the money wage, $b$ the labor-output ratio (inverse of productivity), $e$ the exchange rate (dollars to foreign currency), $P^{*}$ the border price of imports, and $m$ an import coefficient. Labor income is $w b X$ so that the wage rate should be included in determination of nominal GDP. Costs feed into price increases.

Why labor cost is rarely included in econometric macro models dates back to the origins of the Phillips curve itself. A paper by Paul Samuelson and Robert Solow (1960) played a central role in influencing inflation econometrics for decades. They (sort of) estimated a curve with the CPI, not William Phillips's (1958) wages, on the vertical axis.

The lead terms in the GDP = GDI accounting balance simplify to

$$
P C=\pi X+w b X .
$$

This version could be estimated as a cost function for output,

$$
P c X=\pi X+w b X
$$

The money wage should appear on the right-hand side. Samuelson and Solow worked with

$$
C P I=A+B u
$$

with $u$ as unemployment. This formulation is basically microeconomic, with an output-related variable driving a price. Because there is no wage on the right, the equation is mis-specified and subject to missing variable instability and bias. From national accounting, the CPI as the main component of GDP must include both wages and output or employment as contributors to cost.

For 60 years econometricians have been using versions of the Samuelson-Solow equation to ask whether or not a Phillips curve for prices exists. The answer - a huge waste of time and effort -- 
seems pretty clear. The wrong Phillips relationship sinks hope for "inflation targeting" and gives a twist to the Biden trilemma.

In the third equation the central bank sets the expected rate of interest according to its estimate of the natural rate of interest $\left(r^{*}\right)$, hiking it when expected inflation exceeds the government's target:

$r^{e}=r^{*}+\phi\left(\hat{P}^{e}-\hat{P}^{*}\right)$

where $\phi>0$ is the response parameter for the natural rate, supposedly slow in the US during the late 1960s and most of 1970s, until Volcker set things straight.

Fourth and finally comes D'Artagnan, that is, the hypothesis about expected inflation. Most central banks specify expected inflation as weighted average of effective inflation and the state of long-run expectations $\left(\hat{P}^{*}\right)$ :

$\hat{P}^{e}=\theta \hat{P}+(1-\theta) \hat{P}^{*}$

where $0<\theta<1$ measures the degree of price inertia, i.e. how much current inflation to incorporate in expectations. If expectations are anchored, $\hat{P}^{*}$ is the government's target. To follow the New Keynesian story, we will proceed under this assumption even though there is no reason for expected inflation to equal the Fed's target.

These four equations are a linear system for four variables, of the kind one learns to solve in high school. Focusing on the solution for inflation, if there are no demand or price shocks to the economy:

$\hat{P}=\hat{P}^{*}+\frac{\alpha}{1-\theta}\left(y-y^{*}\right)=\hat{P}^{*}+\frac{\alpha \gamma}{1-\theta}\left[\left(\frac{y_{A}-y^{*}}{\gamma}\right)-r^{e}\right]=\hat{P}^{*}+\frac{\alpha \gamma}{1-\theta}\left(r^{*}-r^{e}\right)$

In words, inflation will be on target $\left(\widehat{P}=\hat{P}^{*}\right)$ if and only if the central bank drives the expected rate of interest to the natural rate of interest $\left(r^{*}-r^{e}\right)$. The latter depends on the autonomous component of demand $\left(y_{A}\right)$, potential output $\left(y^{*}\right)$, and the impact of monetary policy on demand $(\gamma)$.

In this convoluted fashion, central bankers and academics extended rational expectations to inflation targeting by the 1990s, with the econometricians spending 30-odd years debating whether or not a Phillips curve exists - no answer as yet. In any case, and under normal conditions (no secular stagnation), the central bank is supposed to announce a target and macro forces will push the inflation rate toward it. No doubt the Fed monitors labor markets closely, but in its public pronouncements it relies on an expected inflation number, without stating the money wage dynamics necessary to reach it. 
Marketing soon came into the picture. Traditionally, Fed chairs used homely metaphors to illustrate their policy goals. ${ }^{10}$ In the 1990 s the statements became more technocratic, implying that the same phantom expected inflation rate haunts all and sundry. The assumption of shared expectations metamorphosed into inflation targeting.

\section{Structuralist inflation}

The contrast with cost-based structuralist inflation theory is clear. It focuses on distributional tensions that stoke growth in costs and prices. A convenient label is "conflicting claims" to income or wealth. We concentrate on income here.

\section{Conflicting claims}

Wicksell had already pointed out that inflation is a "cumulative process" involving feedback between price and wage inflation rates. Even after their long decline, labor payments still make up over half of US production costs and have to enter inflation accounting. Figure 8 is a common non-Wicksellian illustration of how the price level (not the growth rate of prices, or inflation) might be determined. The diagram's key assumption is that the nominal cost of production (a mark-up on the money wage) is constant when output is below the "full capacity" or NAPRU level $X_{1}$. A relatively low level of demand will peg output at $X_{0}$ and the price level at $P_{0}$. An increase in demand will presumably increase the price to $P_{1}$. The extra revenue has to go somewhere. If it flows into profits, it will push up the mark-up and reduce the labor share.

${ }^{10}$ The uselessness of lowering interest rates when banks do not wish to lend ("Pushing on a string," Marriner Eccles, 1935), or intervening to reduce aggregate demand ("Take away the punch bowl just as the party gets going," William McChesney Martin Jr., 1955). ("If we don’t reduce spending ... you will have a recession that will curl your hair," George Humphery, Treasury Secretary, 1957). (“A significant move up in inflation that's also persistent before raising rates...," Jerome Powell, 2019) 


\section{Figure 8: Price level determination}

\section{Price level $P$}

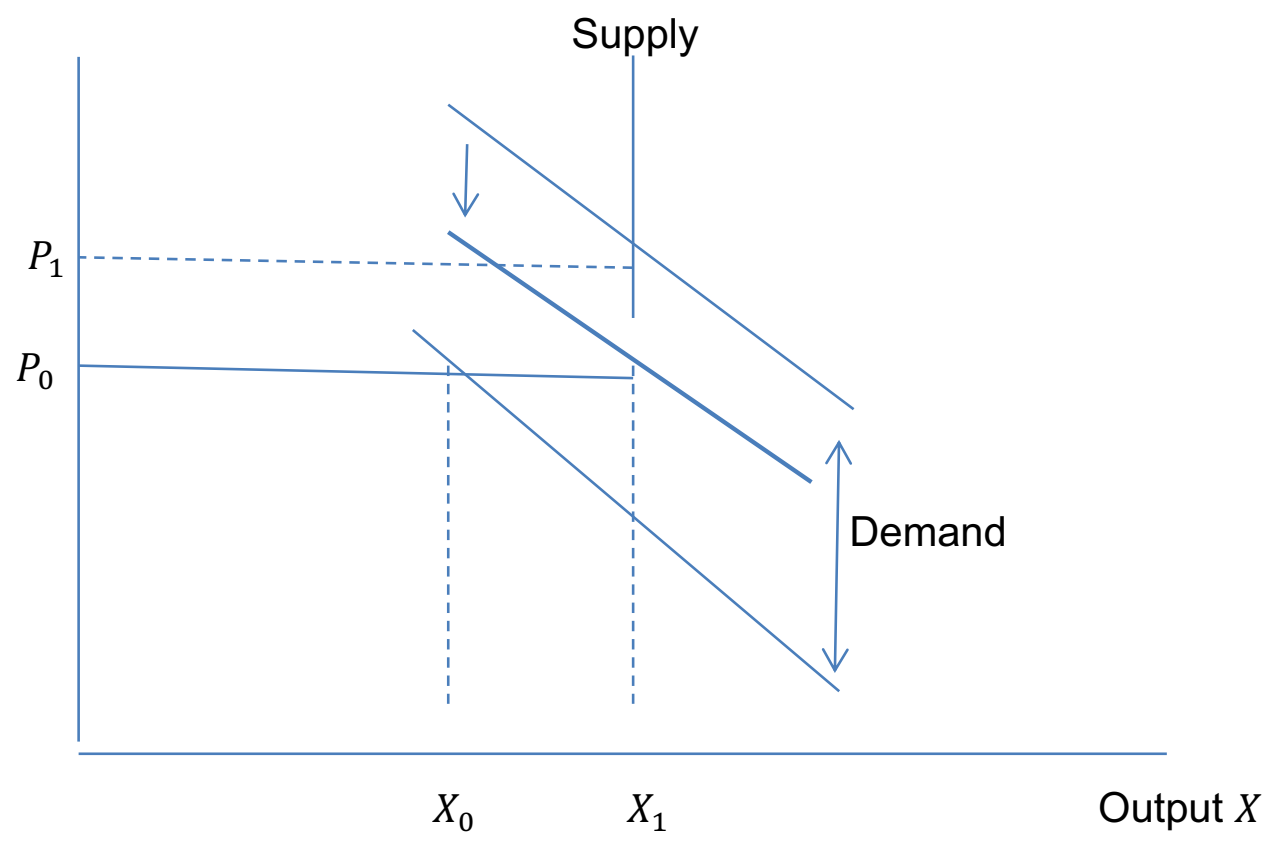

This model violates macroeconomic accounting restrictions. If output cannot exceed capacity, then some mechanism must force the demand schedule to slide downward to the kink in the supply curve, as shown by the heavy line in the diagram. Two possibilities are forced saving and the inflation tax mentioned above. The former probably matters more than real balances. If an expansionary package does drive up the price level, middle class and low income households who rely on wages would be the likely ones to suffer.

\section{Inflation dynamics}

Fortunately, the model of Figure 8 can be extended to more plausible conflicting claims inflation. Conflict arises because price increases are controlled by business while the money wage is subject to bargaining between business and labor. Both sides seek to manipulate the labor share as a key distributional indicator. 


\section{Figure 9: Inflation dynamics}

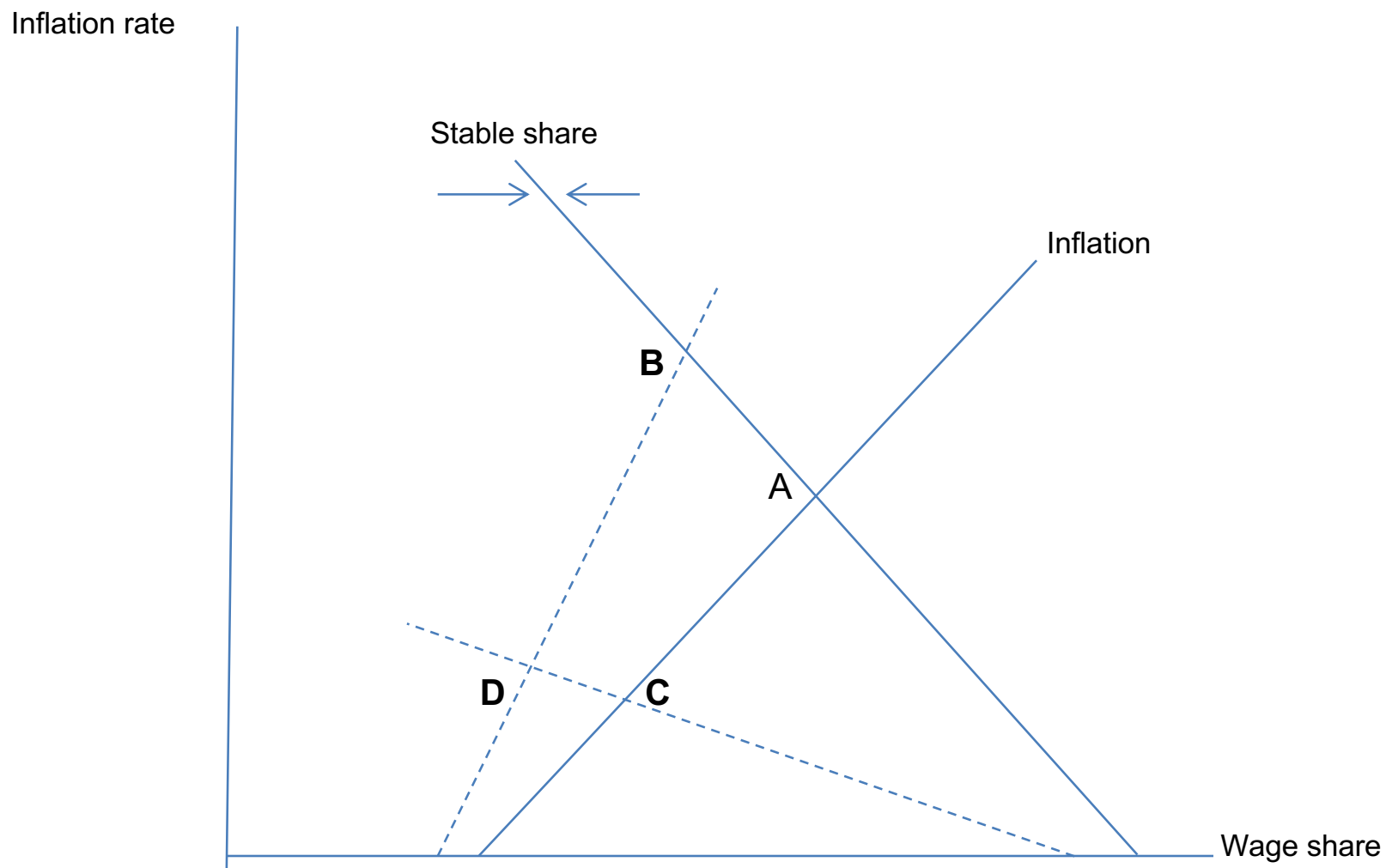

In an overall inflationary environment, business can respond immediately to increases in the wage share or output by boosting the rate of price increase in Phillips curve fashion along the "Inflation" schedule in Figure 9. Money wages on the other hand are not immediately indexed to price inflation so that they will follow with a lag. Labor will push for faster wage inflation when the wage share is low. The "Stable share" schedule with a negative slope will emerge from this bargaining. It will be steeper, the stronger is labor's market power. The small arrows show that if the labor share is low (or high) then it will tend to rise (or fall) until it hits the stability curve. Suppose that there is an initial inflation equilibrium at point A. Using fiscal or monetary policy to stimulate aggregate demand would shift the inflation locus upward (dashed line) with more rapid inflation and a somewhat lower wage share in macro equilibrium at B along the Stable share schedule. In light of the vanishing NAIRU over the past two decades, it is not clear how strong this upward shift could be.

Alternatively, under wage repression, the ability of workers to attain a high wage share could be weak, as illustrated by the dashed stability locus with a shallow slope. In response to expansionary policy beginning at $\mathrm{C}$, there would be a modest increase in inflation and a 
substantially lower wage share ending up at D. Wage repression would stave off inflation under any fiscal or monetary expansion.

The way that expansionary policy could pay off in terms of inequality and (possibly) faster inflation would be through an upward shift in the Stable share schedule if the labor market tightens. Even though measured unemployment plummeted over the past decade, underemployment remains. As noted above, there has been a big employment shift (14\% of the labor force between 1990 and the mid-2000) toward producing sectors with low wages and productivity and slow productivity growth (Taylor with Ömer, 2020). Aggressive demand stimulus could reverse this trend. Obviously, there are complicating factors, but a useful summary of the model in the appendix is that the incoming Biden administration faces a trilemma among income distribution, inflation, and the returns to and prices of assets.

\section{Complications with policy}

No central bank Governor is about to advise business to increase wages faster than current CPI inflation plus productivity growth to drive up costs and the rate of price increases - that is not how they think and if they have other ideas they keep them quiet. As we have seen, their public relations spin shifted from homilies to hints about inflation targets, but the message remains the same.

Wealth transfers are certainly one factor complicating policy. Figure 7 shows how the cost-based GDP deflator is linked to the falling short-term Fed funds rate. Capitalization happens. The value of a real or financial asset is its return -- to a great extent in the form of capital gains -divided by the real interest rate. Low rates have supported huge capital value increases which mostly accrued to the top ten percent of households in the income size distribution.

Part of the marketing for the Fed policy of holding interest rates down is that this increase in spending power due to asset prices increases is supposed to have stimulated consumption demand. Between 2016 and 2020 stock market and household equity rose by about $\$ 2.5$ trillion per year in a $\$ 20$ trillion economy. A typical estimate of consumption from higher wealth is four percent, implying a trivial consumption boost of around $\$ 100$ billion per year.

Another channel for transfers to the affluent takes the form of stock buybacks by S\&P 500 firms. They shot up to close to a trillion dollars per year. After 2008, non-financial corporate debt rose by $\$ 2.8$ trillion while S\&P firms' buybacks totaled $\$ 5.4$ trillion. Evidently, business tapped profits, debt, and recently the proceeds from the Trump tax cut to buy up their own equity. This portfolio shift toward households probably added a few tens of billions to the consumption boost.

Now contrast the position of households in the bottom deciles of the size distribution. They have low positive or negative saving rates - demand in the USA is low-income led (Taylor with Ömer, 2020). Suppose they received a transfer of \$2.5 trillion. Because they are "taxed" at over thirty percent in terms of reduced benefits when they get extra money, they might spend well over an extra trillion on consumption - an order of magnitude higher than affluent households. 
Using capital gains and tax-cut financed share buybacks to support aggregate demand is both inefficient and unethical.

Fiscal debt is another fear in the background. Though not immediate there is potential danger because greater labor militancy could drive up the inflation and real interest rates and cause debt growth to increase, with potentially difficult consequences for the Treasury. Capital flight would be the big danger, but for now the risk is low because the almighty dollar remains the dominant store of international wealth.

More immediately, given the increasing impact of imports on unit costs illustrated in Figure 2, the US exchange rate (dollars per unit of foreign currency) plays a role. ${ }^{11}$ A devaluation or increase in the rate will drive up supply cost directly, but also reduce wage cost per unit output. In addition, dollar devaluation tends to drive up commodity prices, giving another inflationary push.

To take just one example of the policy impact, in 1994 there was maneuvering within the Treasury for modest devaluation. To protect its transaction fees, Wall Street immediately went to incoming Secretary Robert Rubin who pronounced that "A strong dollar is in our national interest," and instituted an anti-inflationary Strong Dollar Policy which persists today. The resemblance to J. P. Morgan and the Gold Standard a century before is striking. Still in the background was the shade of William Jennings Bryan, whose concern for the disadvantaged came to the fore with the New Deal but then faded.

\section{The Biden Trilemma}

What range of policy options will the new administration have? To sharpen intuition. look back at Figure 4. After 1990, subject to cyclical fluctuations, the labor share of gross income fell by four or five percentage points (pp). The GDP deflator fell by about two pp and wage inflation by more. The visual impression supports the VEC and single-equation econometric results in the technical appendix below.

For several years, money wage growth would have to exceed productivity growth by one pp annually for the Fed to attain a target of three percent price inflation. Translating that experience into policy formulation under the incoming Biden administration underlines the difficulties of a trilemma that the new team faces. There are contradictions among three competing objectives, already subject to the difficulties just mentioned:

Money wage growth must exceed the sum of growth rates of prices and productivity if the huge increase in inequality in the size distribution of income since 1970 is ever to be reversed. Low incomes depend heavily on wages and fiscal transfers, and political possibilities for increases in the latter are likely to be limited.

\footnotetext{
${ }^{11}$ Although it is confusing, this definition of the exchange rate is standard in open economy macroeconomics.
} 
Consequently, the inflation rate would increase as firms pass higher costs into higher prices. The Fed's two percent target could be breached, at which point the authorities could well move toward demand contraction.

For the reasons discussed in connection with Figure 7, faster inflation would drive up interest rates, forcing asset prices down with capitalization running in reverse, driving up costs of servicing private and fiscal debt, and cutting into financial fees. Vociferous responses (at the very least) could be expected from Wall Street and affluent households. The Fed's floor under interest rates when asset prices wobble could well be a flashpoint. It has been in place now for 35 years and is Holy Writ for Wall Street.

The new administration's economic priorities seem clear. Achieving them will be a tremendously difficult task, even ignoring the numerous other complications. 


\section{Technical Appendix}

Assuming that money is endogenous because Central Banks target the rate of interest and the velocity of circulation varies according to the economy's demand for liquidity, we need to look for price determination outside the equation of exchange. The obvious candidate is the cost composition of production, that is, the fact that the gross value of everything produced can be decomposed in gross profits, total wages, and intermediate inputs.

Gross profits include depreciation, interest payments, and direct and indirect taxes. Total wages also include taxes (income and payroll), as well as contributions to private insurance plans. Intermediate inputs can be domestic or imported, with the latter determined by international prices and the nominal exchange rate. In this context, the final price of each product depends on technology (how much labor and inputs are needed per unit of production), import prices, and social conflict (how much of the value added to inputs goes to taxes, profits, and wages).

Focusing on consumer prices and using the fact that the price of domestic inputs can be expressed in terms of taxes, profits, wages and import prices, we can work with the following definition:

$$
P=Z+w B+e P_{M}^{f} A_{M}
$$

where $Z$ is the gross profit per unit of production, $w$ the nominal wage, $B$ the amount of hours per unit of production (the inverse of labor productivity), $e$ the exchange rate expressed as the domestic price of international currency (for example: USD per Euros), $P_{M}^{f}$ the price of imports in foreign currency, and $A_{M}$ the amount of imported inputs per unit of output.

Without much theory, the equation just says that domestic prices are determined by social conflict $(Z$ and $w)$, technology $\left(B\right.$ and $\left.A_{M}\right)$ and import prices $\left(e P_{M}^{f}\right)$. Assuming the other components of the price level stay fixed, an increase in the nominal wage tends to be transmitted to prices. This is the usual source of inflation emphasized by most mainstream models up until 2008.

More technically, as labor productivity grows, $B$ falls in (1), allowing $w$ to increase as fast as the fall in $B$ without creating any inflationary pressure. However, if $w$ increases faster than productivity $(1 / B), w B$ grows and this pushes the price up. Most New Keynesian models of the Phillips Curve smooth this relationship imposing some sort of price rigidity on the firms' behavior.

However, from a pure accounting perspective, inflation can also come from an increase in the price of imports, due to a depreciation of the USD (an increase in $e$ ) or an adverse shock to international prices (an increase in $P_{e}^{f}$ ). The same holds for the gross profit per unit of production $(Z)$, which is a negative function of the labor share of income. The logic of the latter effect is that, given the technical coefficients of production, a higher labor share reduces the 
profit per unit of output and leads firms to raise prices. So, in addition to "excessive nominal wage growth" from a tight labor market, inflation can also come from an "excessive desired rate of profit" in structuralist models. The two effects have the same importance, but changes in the firms' mark-up over cost have not been emphasized by most mainstream models on the assumption that capital receives its fair and constant share of output under perfect competition (the New Classical approach), or that market power does not vary much under imperfect competition (the New Keynesian approach until recently).

In fact, following Friedman's adaptation of Wicksell's ideas to the $20^{\text {th }}$ century, until 2008 , most mainstream models described inflation as the result of "excessive wage claims" on output. If the firms' mark-up implicit in $Z$ do not change much and import prices are not too volatile, by the sheer force of accounting, most of the variation of $P$ must come from $w B$ in the price equation. But does this view hold in practice? The answer is no for two obvious reasons.

First, since the breakdown of the Bretton-Woods monetary system, the world embarked on a period of floating and volatile exchange rates, together with volatile international prices, especially of non-renewable commodities such as oil and minerals. As a result, there have been many commodity and currency super cycles in the last 40 years, with clear impacts on US consumer inflation.

The international component of inflation also depends on industrial prices and supply chains in global manufacturing output especially of East Asia. It has been a major deflationary force on US consumer prices since at least the 1980s.

Second, in addition to international issues, the US also initiated a period of wage repression since the 1980s, with a reduction in unionization and in the real value of the minimum wage, together with weaker employment protection legislation (Taylor with Ömer 2020). This move alone would have raised profits per unit of output. Coupled with international pressures, the result of wage repression has been a substantial reduction in the labor share of US income, especially from the 1990s onwards, as mentioned earlier.

In terms of inflation theories, the structuralist model puts market power (measured by the labor share) and import prices at the same level of importance as demand pressures to explain inflation. For example, there can be periods of high employment and no discernible inflationary pressures because of a reduction in the labor share and collapsing import prices (the US in the mid-1990s). In the same vein, even with high unemployment, there can be an increase in inflation due to a rise in the labor share (profit squeeze) and adverse shocks in some the key inputs (the US in the 1970s).

\section{Time Series Evidence}

To illustrate the point, we estimated a simple model of US consumer inflation from wage pressures, import prices and changes in the distribution of income. The basic idea was to check the importance of each factor when the others were held constant. The data come from the US 
national accounts and labor market. The sample includes quarterly observations from 1948 up to the $3^{\text {rd }}$ quarter of 2020, but to exclude the effects of Covid-19 pandemic, we restricted our analysis to the 1948-2019 period.

The econometrics assumes that there is a long-run relationship between inflation on one side, and import prices, the rate of unemployment, and the labor share on the other. These four variables are cointegrated, meaning that, given an exogenous shock to any of them, all show short-run fluctuations as they return to their long-run relationship.

The relationship does not need to be constant and there is evidence that it did change in the US, as we will see in a moment. Before that, let us present the series.

The Inflation rate corresponds to the quarterly change in the log price index of private consumer expenditures (P_PCE), a variable that is highly correlated with the consumer price index (CPI) used by the Fed (Figure 10). We prefer the PCE over the CPI because of correlation with consumer and import prices (Figure 11).

The labor share is the share of labor compensation (wages plus supplementary labor income) in the Net Domestic Income (LSNDI), that is GDP minus capital consumption plus the statistical discrepancy between the estimates of value added from the income and production accounts of the US economy. The rate of unemployment covers the civilian population (U_RATE_SA) and all series are seasonally adjusted.

Before we present the econometric model, we should repeat that the rate of unemployment and the labor share exhibit a Marx-Goodwin cycle in the US, that is, a "predator-prey" dynamic in which fluctuations in the rate of unemployment (predator) "chase" fluctuations in the labor share (prey), with perpetual cycles around a moving steady state. Figure 12 shows the time paths. 
Figure 10: PCE and CPI annual inflation, measured as the log difference of price in relation of its level in the same quarter of the previous year, shaded areas represent NBER recessions.

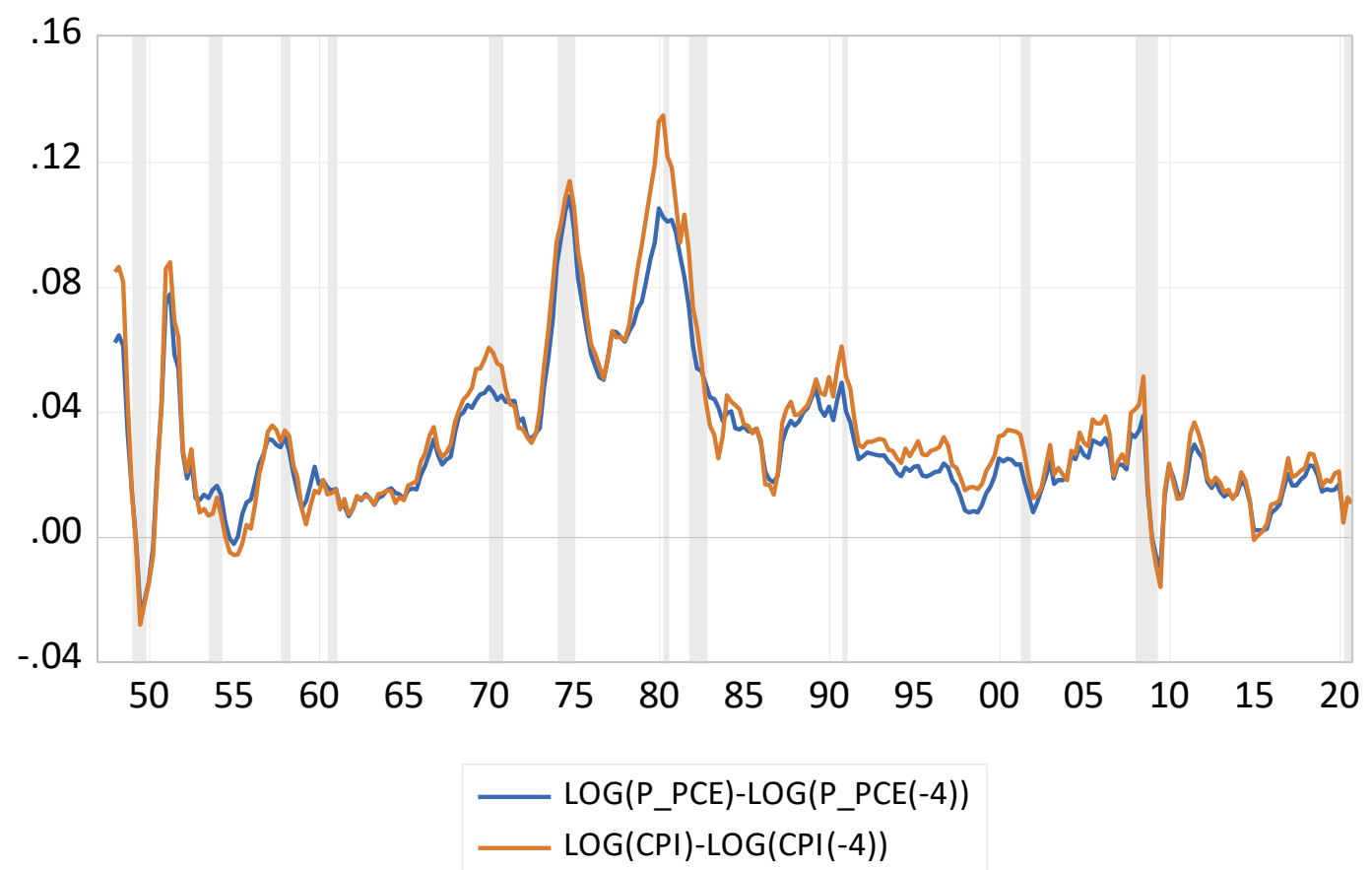

Source: BEA, BLS, and NBER, authors' elaboration.

We assume that the four series under analysis are stationary. This is obviously true for the labor share and the rate of unemployment, since the two variables are bounded between zero and one. In the case of consumer and imported inflation, the shocks and high inflation volatility of the 1970s and 1980s may indicate a unit-root, but this does not make much economic sense, unless one considers "hyperinflation" and "hyperdeflation" a recurring phenomenon in the US.

Common sense and economic history justify assuming that US inflation has been stationary since the late 1940s because one of the main concerns of the macroeconomic policy of the period has been precisely to stabilize inflation. 
Figure 11: Consumer-price (P_PCE) and import-price (P_IMP) annual inflation, measured as the log difference of price in relation of its level in the same quarter of the previous year, consumer inflation in the left axis, import inflation in the right axis, shaded areas represent NBER recessions.

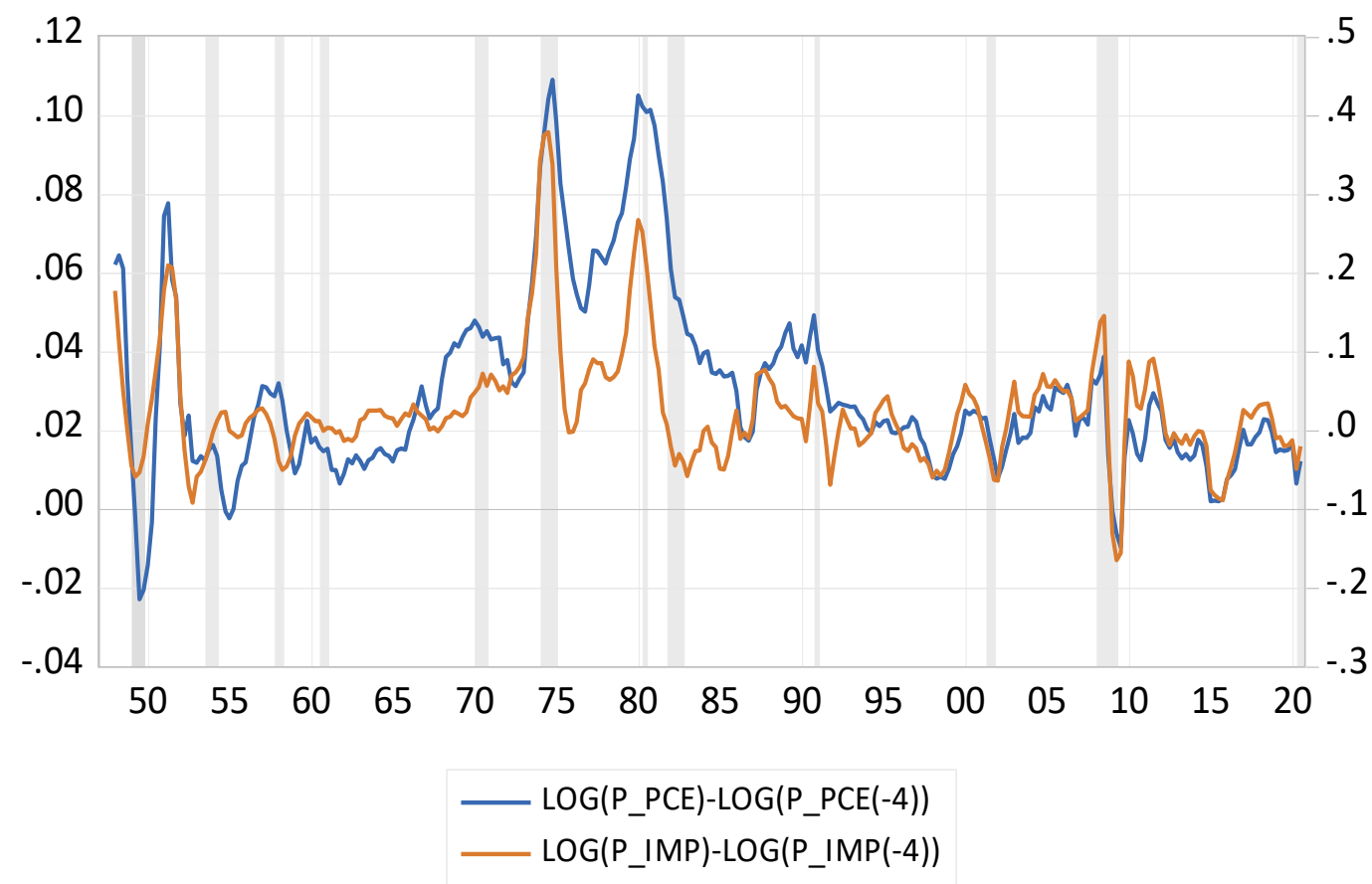

The usual statistical tests confirm common sense, indicating that, at $1 \%$ of statistical significance, consumer-price and import-price inflation do not have a unit root. ${ }^{12}$ The same holds for the rate of unemployment, but not for the labor share, probably because of structural breaks in the early 1950s (the Korean War), the late 1960s (the escalation of the Vietnam War), and the mid-1990s (wage repression and secular stagnation). ${ }^{13}$ Despite the latter statistical result, we will proceed first under the assumption that the labor share does not have a unit root, and then deal with possible structural breaks estimating the model for alternative subsamples.

\footnotetext{
${ }^{12}$ We ran the Augmented Dickey-Fuller test, with an endogenous selection of lag length starting from 15 quarters downward.

${ }^{13}$ To confirm this we estimated an $\operatorname{ARMA}(4,4)$ model for the labor share and did a Chow breakpoint test for the first quarters of 1952, 1968, and 1995. The results reject the null hypothesis of no structural breaks at the specified dates at $0.01 \%$ of statistical significance.
} 
Figure 12: rate of unemployment (U_RATE_SA) and labor share of net domestic income (LSNDI), shaded areas represent NBER recessions.

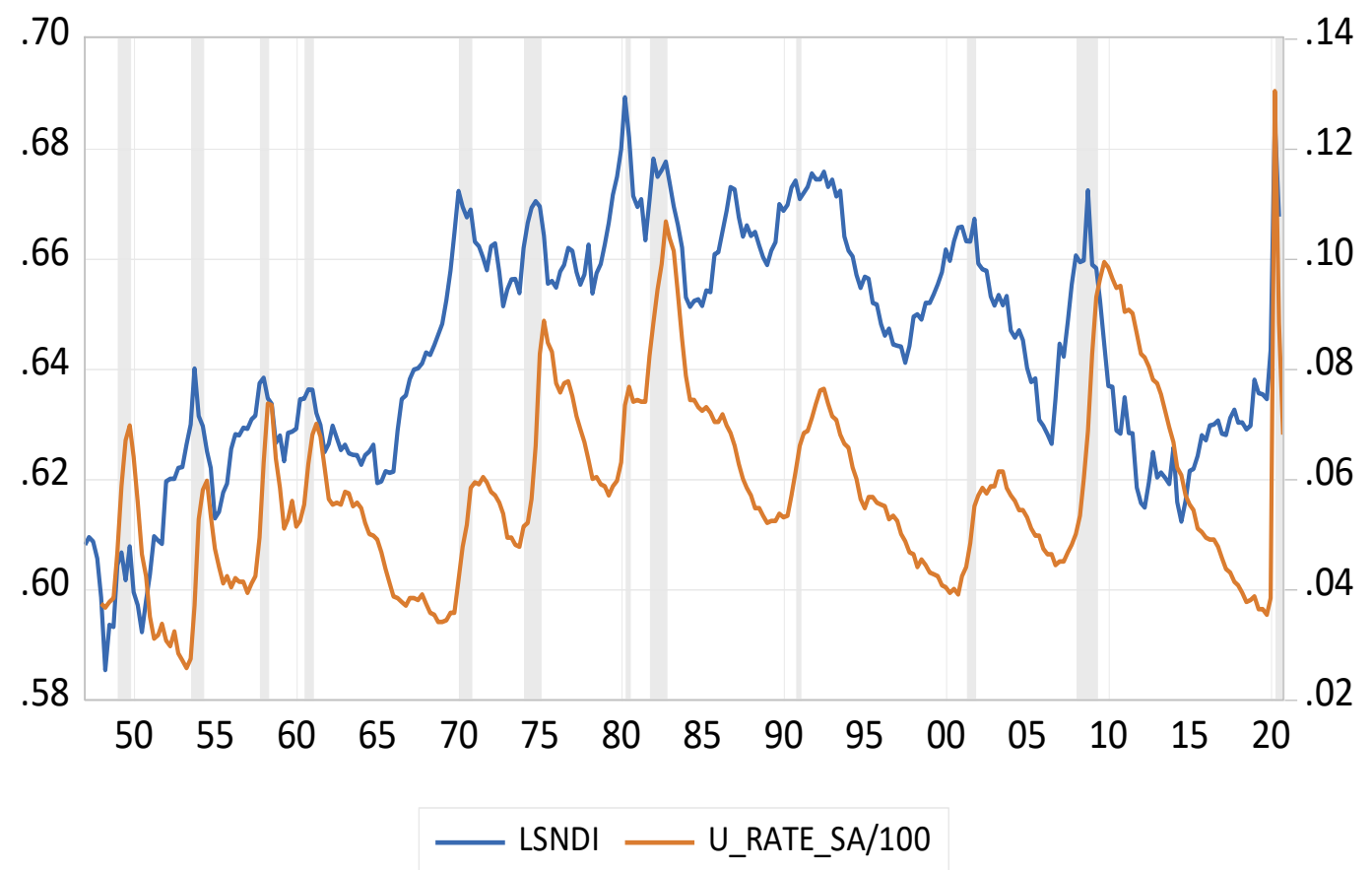

Source: BEA and NBER, authors' elaboration

\section{Sample and structural breaks}

The whole sample covers 71 years, from 1948 until 2019, or 284 quarters. The US economy surely passed through many structural breaks over the years. We will deal with this by estimating the model for alternative periods. The subsamples take NBER business-cycle dates as references. The principal focus is on the recent period, from the early 1990s onwards, during which the labor share of US income had a downward trend.

Based on the NBER dating (Table 1) and our evaluation of the recent US economic history, we adopted the following division of the last 72 years:

1. The Bretton-Woods period, from the late 1940s up to the last quarter of 1970.

2. The Great Inflation and Disinflation, from 1971 through the $1^{\text {st }}$ quarter of 1991.

3. The Great Moderation and Secular Stagnation, from the $2^{\text {nd }}$ quarter of 1991 up to the last observation of 2019 (to exclude the Covid-19 from the sample).

The end of the first period is the NBER trough of the last quarter of 1970. Considering that Nixon abandoned the gold-dollar peg in August 1971, this break also coincides with a major institutional change in the US. 
Table 1: NBER business-cycle dates since 1945

\begin{tabular}{|l|l|l|l|l|l|l|l|l|l|}
\hline \multicolumn{3}{|c|}{ Business Cycle Reference Dates } & & Contraction & Expansion & \multicolumn{2}{|c|}{ Cycle } \\
\hline $\begin{array}{l}\text { Peak } \\
\text { Month }\end{array}$ & Peak Year & $\begin{array}{l}\text { Peak } \\
\text { Quarter }\end{array}$ & $\begin{array}{l}\text { Trough } \\
\text { Month }\end{array}$ & $\begin{array}{l}\text { Trough } \\
\text { Year }\end{array}$ & $\begin{array}{l}\text { Trough } \\
\text { Quarter }\end{array}$ & $\begin{array}{l}\text { Peak to } \\
\text { Trough } \\
\text { (Months) }\end{array}$ & $\begin{array}{l}\text { Previous } \\
\text { Trough to } \\
\text { this Peak } \\
\text { (Months) }\end{array}$ & $\begin{array}{l}\text { Trough } \\
\text { from } \\
\text { Previous } \\
\text { Trough } \\
\text { (Months) }\end{array}$ & $\begin{array}{l}\text { Peak from } \\
\text { Previous } \\
\text { Peak } \\
\text { (Months) }\end{array}$ \\
\hline February & 1945 & 1 & October & 1945 & 4 & 8 & 80 & 88 & 93 \\
\hline November & 1948 & 4 & October & 1949 & 4 & 11 & 37 & 48 & 45 \\
\hline July & 1953 & 2 & May & 1954 & 2 & 10 & 45 & 55 & 56 \\
\hline August & 1957 & 3 & April & 1958 & 2 & 8 & 39 & 47 & 49 \\
\hline April & 1960 & 2 & February & 1961 & 1 & 10 & 24 & 34 & 32 \\
\hline December & 1969 & 4 & November & 1970 & 4 & 11 & 106 & 117 & 116 \\
\hline November & 1973 & 4 & March & 1975 & 1 & 16 & 36 & 52 & 47 \\
\hline January & 1980 & 1 & July & 1980 & 3 & 6 & 58 & 64 & 74 \\
\hline July & 1981 & 3 & November & 1982 & 4 & 16 & 12 & 28 & 18 \\
\hline July & 1990 & 3 & March & 1991 & 1 & 8 & 92 & 100 & 108 \\
\hline March & 2001 & 1 & November & 2001 & 4 & 8 & 120 & 128 & 128 \\
\hline December & 2007 & 4 & June & 2009 & 2 & 18 & 73 & 91 & 8 \\
\hline February & 2020 & - & - & - & - & - & 128 & - & 146 \\
\hline
\end{tabular}

Source: NBER

The end of the second sub-period is the NBER trough at the beginning of 1991, which marks the end of the disinflation that started in the early 1980s. There was no substantial domestic change in the US in the early 1990s, but there was the fall of communism and the triumph of the neoliberal agenda in the rest of the world. We chose 1991 as our second breakpoint for two reasons: (i) the 1970s and 1980s can be portrayed as a common period if we consider that the adverse oil shocks and dollar depreciation of the mid 1970s were compensated by the collapse of the price of oil and the dollar appreciation of the early 1980s; and (ii) the consumer inflation series seem to have had a downward shift in the early 1990 s, averaging $1.8 \%$ per year since then. ${ }^{14}$ To put the latter number in perspective, average annual inflation was $2.3 \%$ during the Bretton-Woods period and 5.3.\% during the Great Inflation and Disinflation of the 1970s and 1980 .

\section{Causality tests}

To check the relationship between the variables without imposing too much economic theory on the data, we ran a series of Granger causality tests, one for each pair of variables and sample, with either 2 or 4 lags in the model. Table 2 presents the results and, at $5 \%$ of statistical significance, for the whole sample, we can say that:

${ }^{14}$ To test this we estimated an $\operatorname{ARMA}(4,4)$ model for consumer inflation and did another Chow test, with breakpoint in the last quarter of 1970 and first quarter of 1991. The result is that we cannot reject the null hypothesis of no breaks in both dates at $0.01 \%$ of statistical significance. 
- $\quad$ Consumer-price and import-price inflation cause each other when we include 4 lags in the model (the US affects and is affected by the rest of the world).

- $\quad$ The rate of unemployment and consumer inflation also cause each other, with either 2 or 4 lags in the model (strong evidence of a Phillips curve).

- $\quad$ The labor share and consumer inflation cause each other with 2 lags, but when we do the same test with 4 lags, causality runs "only" from inflation to the labor share (there is stronger evidence of the impact of inflation on income distribution than vice versa).

- $\quad$ The labor share and the rate of unemployment cause each other with either 2 or 4 lags in the model (strong evidence of Goodwin cycles).

The rate of unemployment seems to have caused consumer inflation during the Bretton Woods period, but not the other way around, in a classic Phillips curve (no wonder studies of the period stressed this point). And on social conflict, the rate of unemployment seems to have caused changes in the labor share, as emphasized by Goodwin at that time.

The situation changed during the Great Inflation and Disinflation of the 1970s and 1980s, when consumer and import-price inflation exhibited a two-way causal relationship (in the model with 2 lags). The relationship between inflation and the labor market also seems to have changed, with inflation causing unemployment (stagflation) rather than the other way around. In contrast, the labor share seemed to cause consumer inflation but not the rate of unemployment (wither Goodwin), while the rate of unemployment seemed to cause changes in import-price inflation (the Volcker shock driving world prices).

The situation changed once more from 1991 through 2019, when import-price inflation seems to cause consumer inflation, but not the other way around (the world driving US consumer prices). The reverse Phillips curve continued to appear in the data, with changes in consumer inflation causing changes in the rate of unemployment instead of the other way around. Import-price inflation also seems to have caused the rate of unemployment (the world driving the US labor market), while the Goodwin cycle reappeared strongly in the data, with a two-way causality between the labor share and the rate of unemployment. 
Table 2: pairwise Granger causality tests

\begin{tabular}{|c|c|c|c|c|c|c|c|c|c|c|c|c|}
\hline \multirow{3}{*}{ Null Hypothesis: } & \multicolumn{6}{|c|}{ Whole sample (1948-2019) } & \multicolumn{6}{|c|}{ Bretton-Woods (1948-70) } \\
\hline & \multicolumn{3}{|c|}{ Model with 4 lags } & \multicolumn{3}{|c|}{ Model with 2 lags } & \multicolumn{3}{|c|}{ Model with 4 lags } & \multicolumn{3}{|c|}{ Model with 2 lags } \\
\hline & Obs & F-Statistic & Prob. & Obs & F-Statistic & Prob. & Obs & F-Statistic & Prob. & Obs & F-Statistic & Prob. \\
\hline DLOG(P_IMP) does not Granger Cause DLOG(P_PCE) & 287 & 2.5832 & $3.8 \%$ & 288 & 2.743 & $6.6 \%$ & 91 & 0.98157 & $42.2 \%$ & 92 & 2.76176 & $6.9 \%$ \\
\hline DLOG(P_PCE) does not Granger Cause DLOG(P IMP) & & 4.1713 & $0.3 \%$ & & 2.328 & $9.9 \%$ & & 8.59698 & $0.0 \%$ & & 0.46663 & $62.9 \%$ \\
\hline U_RATE_SA/100 does not Granger Cause DLOG(P_PCE) & 284 & 2.8861 & $2.3 \%$ & 286 & 3.288 & $3.9 \%$ & 88 & 2.46536 & $5.2 \%$ & 90 & 3.75498 & $2.7 \%$ \\
\hline DLOG(P_PCE) does not Granger Cause U_RATE_SA/100 & & 4.2261 & $0.3 \%$ & & 5.727 & $0.4 \%$ & & 0.89895 & $46.9 \%$ & & 0.86388 & $42.5 \%$ \\
\hline LSNDI does not Granger Cause DLOG(P_PCE) & 287 & 1.5809 & $18.0 \%$ & 288 & 3.533 & $3.1 \%$ & 91 & 1.50381 & $20.9 \%$ & 92 & 1.50332 & $22.8 \%$ \\
\hline DLOG(P_PCE) does not Granger Cause LSNDI & & 3.9536 & $0.4 \%$ & & 5.424 & $0.5 \%$ & & 2.43339 & $5.4 \%$ & & 1.6938 & $19.0 \%$ \\
\hline U_RATE_SA/100 does not Granger Cause DLOG(P_IMP) & 284 & 0.7165 & $58.1 \%$ & 286 & 0.822 & $44.1 \%$ & 88 & 0.60888 & $65.7 \%$ & 90 & 1.21386 & $30.2 \%$ \\
\hline DLOG(P_IMP) does not Granger Cause U_RATE_SA/100 & & 3.1830 & $1.4 \%$ & & 4.837 & $0.9 \%$ & & 0.93345 & $44.9 \%$ & & 0.5945 & $55.4 \%$ \\
\hline LSNDI does not Granger Cause DLOG(P_IMP) & 287 & 0.4838 & $74.8 \%$ & 288 & 0.701 & $49.7 \%$ & 91 & 1.53449 & $20.0 \%$ & 92 & 1.63972 & $20.0 \%$ \\
\hline DLOG(P_IMP) does not Granger Cause LSNDI & & 1.3575 & $24.9 \%$ & & 1.993 & $13.8 \%$ & & 0.25005 & $90.9 \%$ & & 0.07517 & $92.8 \%$ \\
\hline LSNDI does not Granger Cause U_RATE_SA/100 & 284 & 5.1683 & $0.1 \%$ & 286 & 6.874 & $0.1 \%$ & 88 & 1.91302 & $11.6 \%$ & 90 & 1.74566 & $18.1 \%$ \\
\hline U_RATE_SA/100 does not Granger Cause LSNDI & & 9.4928 & $0.0 \%$ & & 14.905 & $0.0 \%$ & & 8.56416 & $0.0 \%$ & & 18.4709 & $0.0 \%$ \\
\hline \multirow{3}{*}{ Null Hypothesis: } & \multicolumn{6}{|c|}{ Great Inflation and Disinflation (1971-90) } & \multicolumn{6}{|c|}{ Great Moderation and Secular Stagnation (1991-2019) } \\
\hline & \multicolumn{3}{|c|}{ Model with 4 lags } & \multicolumn{3}{|c|}{ Model with 2 lags } & \multicolumn{3}{|c|}{ Model with 4 lags } & \multicolumn{3}{|c|}{ Model with 2 lags } \\
\hline & Obs & F-Statistic & Prob. & Obs & F-Statistic & Prob. & Obs & F-Statistic & Prob. & Obs & F-Statistic & Prob. \\
\hline DLOG(P_IMP) does not Granger Cause DLOG(P_PCE) & 81 & 2.94137 & $2.6 \%$ & 81 & 2.57838 & $8.3 \%$ & 115 & 3.22957 & $1.5 \%$ & 115 & 2.8111 & $6.5 \%$ \\
\hline DLOG(P_PCE) does not Granger Cause DLOG(P_IMP) & & 3.69174 & $0.9 \%$ & & 0.73756 & $48.2 \%$ & & 1.18301 & $32.3 \%$ & & 1.86532 & $16.0 \%$ \\
\hline U_RATE_SA/100 does not Granger Cause DLOG(P_PCE) & 81 & 2.16386 & $8.2 \%$ & 81 & 3.39249 & $3.9 \%$ & 115 & 2.16689 & $7.8 \%$ & 115 & 0.82927 & $43.9 \%$ \\
\hline DLOG(P_PCE) does not Granger Cause U_RATE_SA/100 & & 4.04697 & $0.5 \%$ & & 3.9128 & $2.4 \%$ & & 4.43155 & $0.2 \%$ & & 5.16706 & $0.7 \%$ \\
\hline LSNDI does not Granger Cause DLOG(P_PCE) & 81 & 3.03644 & $2.3 \%$ & 81 & 0.5346 & $58.8 \%$ & 115 & 1.26765 & $28.7 \%$ & 115 & 1.55884 & $21.5 \%$ \\
\hline DLOG(P_PCE) does not Granger Cause LSNDI & & 1.56701 & $19.2 \%$ & & 2.8083 & $6.7 \%$ & & 0.76664 & $54.9 \%$ & & 0.79819 & $45.3 \%$ \\
\hline U_RATE_SA/100 does not Granger Cause DLOG(P_IMP) & 81 & 2.26555 & $7.0 \%$ & 81 & 4.00407 & $2.2 \%$ & 115 & 0.9224 & $45.4 \%$ & 115 & 0.59125 & $55.5 \%$ \\
\hline DLOG(P_IMP) does not Granger Cause U_RATE_SA/100 & & 1.96847 & $10.9 \%$ & & 2.45586 & $9.3 \%$ & & 5.28154 & $0.1 \%$ & & 4.48402 & $1.3 \%$ \\
\hline LSNDI does not Granger Cause DLOG(P_IMP) & 81 & 1.77779 & $14.3 \%$ & 81 & 2.05768 & $13.5 \%$ & 115 & 0.39472 & $81.2 \%$ & 115 & 0.08983 & $91.4 \%$ \\
\hline DLOG(P_IMP) does not Granger Cause LSNDI & & 0.40562 & $80.4 \%$ & & 0.63452 & $53.3 \%$ & & 0.55229 & $69.8 \%$ & & 0.48753 & $61.6 \%$ \\
\hline LSNDI does not Granger Cause U_RATE_SA/100 & 81 & 0.94324 & $44.4 \%$ & 81 & 0.50781 & $60.4 \%$ & 115 & 3.85087 & $0.6 \%$ & 115 & 2.99453 & $5.4 \%$ \\
\hline U_RATE_SA/100 does not Granger Cause LSNDI & & 0.77025 & $54.8 \%$ & & 1.2321 & $29.7 \%$ & & 2.85514 & $2.7 \%$ & & 6.95918 & $0.1 \%$ \\
\hline
\end{tabular}

\section{Source: authors' calculation}

\section{The multivariate and univariate models}

Given the changing nature of pairwise Granger causality between consumer inflation, imported inflation, the rate of unemployment and the labor share, the next question is: what happens when we merge the four variables in a multivariate model? To answer this, we estimated a VectorError-Correction (VEC) of the series, also with two and four lags, for all samples specified earlier. The theoretical assumption is that there exists at least one stable statistical linear combination of the four variables, to which they tend to return after stochastic shocks. From our previous analysis, the main candidates for long-run regularities or stylized facts are the Phillips curve, the Goodwin cycle, the two-way relationship between import prices and consumer prices, or a combination of all three possibilities.

To check for cointegration, we ran the Johansen test with a constant term (intercept) in the cointegrating (long-run) equation, but without any other exogenous variable in the model because this would invalidate the test's statistics. At $1 \%$ of statistical significance, the results indicate the existence of two cointegrating equations of the four variables for the whole sample, with either 2 or 4 lags in the model (Table 3). This result may indicate, for example, the existence of both a Phillips curve and Goodwin cycles in the US economy. 
Table 3: Johansen trace cointegration tests

\begin{tabular}{|c|c|c|c|c|c|c|c|c|}
\hline $\begin{array}{l}\text { Number of } \\
\text { cointegrating }\end{array}$ & & Model wit & ith 4 lags & & & Model wi & ith 2 lags & \\
\hline $\begin{array}{l}\text { Whole sample (trace } \\
\text { test) }\end{array}$ & Eigenvalue & Statistic & $\begin{array}{l}\text { Critical } \\
\text { Value }\end{array}$ & Probability & Eigenvalue & Statistic & $\begin{array}{l}\text { Critical } \\
\text { Value }\end{array}$ & Probability \\
\hline None & 0.1952 & 118.3404 & 54.0790 & $0.0 \%$ & 0.2168 & 133.9458 & 54.0790 & $0.0 \%$ \\
\hline At most 1 & 0.1267 & 56.8908 & 35.1928 & $0.0 \%$ & 0.1432 & 64.2879 & 35.1928 & $0.0 \%$ \\
\hline At most 2 & 0.0395 & 18.5370 & 20.2618 & $8.5 \%$ & 0.0428 & 20.2374 & 20.2618 & $5.0 \%$ \\
\hline At most 3 & 0.0248 & 7.1198 & 9.1645 & $12.0 \%$ & 0.0269 & 7.7826 & 9.1645 & $9.1 \%$ \\
\hline $\begin{array}{l}\text { Bretton-Woods 1948- } \\
70\end{array}$ & Eigenvalue & Statistic & $\begin{array}{l}\text { Critical } \\
\text { Value }\end{array}$ & Probability & Eigenvalue & Statistic & $\begin{array}{l}\text { Critical } \\
\text { Value }\end{array}$ & Probability \\
\hline None & 0.2569 & 62.9385 & 54.0790 & $0.7 \%$ & 0.4095 & 93.5571 & 54.0790 & $0.0 \%$ \\
\hline At most 1 & 0.2006 & 37.1057 & 35.1928 & $3.1 \%$ & 0.2746 & 46.6789 & 35.1928 & $0.2 \%$ \\
\hline At most 2 & 0.1162 & 17.6267 & 20.2618 & $11.1 \%$ & 0.1509 & 18.1131 & 20.2618 & $9.6 \%$ \\
\hline At most 3 & 0.0760 & 6.8812 & 9.1645 & $13.3 \%$ & 0.0391 & 3.5497 & 9.1645 & $48.3 \%$ \\
\hline $\begin{array}{l}\text { Great inflaton and } \\
\text { disinflation 1971-90 }\end{array}$ & Eigenvalue & Statistic & $\begin{array}{l}\text { Critical } \\
\text { Value }\end{array}$ & Probability & Eigenvalue & Statistic & $\begin{array}{l}\text { Critical } \\
\text { Value }\end{array}$ & Probability \\
\hline None & 0.3199 & 67.7974 & 54.0790 & $0.2 \%$ & 0.2725 & 51.0078 & 54.0790 & $9.1 \%$ \\
\hline At most 1 & 0.2862 & 36.5721 & 35.1928 & $3.5 \%$ & 0.1477 & 25.2344 & 35.1928 & $38.6 \%$ \\
\hline At most 2 & 0.0762 & 9.2645 & 20.2618 & $71.1 \%$ & 0.1066 & 12.2928 & 20.2618 & $42.3 \%$ \\
\hline At most 3 & 0.0345 & 2.8414 & 9.1645 & $61.1 \%$ & 0.0383 & 3.1650 & 9.1645 & $55.0 \%$ \\
\hline $\begin{array}{l}\text { Great moderation and } \\
\text { secular stagnation } \\
1991-2019\end{array}$ & Eigenvalue & Statistic & $\begin{array}{l}\text { Critical } \\
\text { Value }\end{array}$ & Probability & Eigenvalue & Statistic & $\begin{array}{l}\text { Critical } \\
\text { Value }\end{array}$ & Probability \\
\hline None & 0.3025 & 69.8151 & 54.0790 & $0.1 \%$ & 0.2657 & 70.5035 & 54.0790 & $0.1 \%$ \\
\hline At most 1 & 0.1350 & 28.3933 & 35.1928 & $22.4 \%$ & 0.1742 & 34.9810 & 35.1928 & $5.3 \%$ \\
\hline At most 2 & 0.0711 & 11.7099 & 20.2618 & $47.5 \%$ & 0.0850 & 12.9760 & 20.2618 & $36.6 \%$ \\
\hline At most 3 & 0.0277 & 3.2341 & 9.1645 & $53.8 \%$ & 0.0238 & 2.7660 & 9.1645 & $62.5 \%$ \\
\hline
\end{tabular}

Source: authors' calculation

When we consider just the Bretton-Woods period, the Johansen test points to two cointegration equations with 2 lags, but just one cointegration with four lags. The Great Inflation and Disinflation of the 1970s and 1980s also seem to have just one cointegrating equation with 4 lags, but no cointegrating equation with 2 lags. The statistical results become robust only in the more recent period, from 1991 through 2019, when the Johansen test indicates just one cointegrating equation with either 2 or 4 lags in the model. Based on the latter finding and on the structuralist theory of inflation outlined earlier, we will analyze just the VEC model of the Great Moderation and Secular Stagnation.

To control for the impact of the 2008 financial crash, we introduced a pulse dummy in the VEC model (D2008Q4=1 in the $4^{\text {th }}$ quarter of 2008) and used the Akaike information criteria to select the best lag specification (between 1 and 4 lags). The best fit occurred with 4 lags and the estimated coefficients pointed to the following long-run relationship between annual consumer 
inflation $\left(\pi_{C}\right)$, annual import-price inflation $\left(\pi_{M}\right)$, the rate of unemployment $(u)$ and the labor share $(l)$ :

$\pi_{C}=-\underbrace{0.105^{*}}_{0.036}+\underbrace{0.207^{*}}_{0.020} \pi_{M}+\underbrace{0.015}_{0.060} u+\underbrace{0.188^{*}}_{0.055} l$

where the number below each estimated coefficient is its standard deviation and " $*$ " means that the estimated value is statistically significant at $1 \%$.

In economic terms, the results mean that a one pp increase in import prices push up US consumer prices approximately $0.207 \mathrm{pp}$. The coefficient for the rate of unemployment has the "wrong sign", meaning that an increase in the rate of unemployment raised inflation in 1991-2019, but its value is low and not statistically significant, even at $10 \%$. In contrast, the coefficient for the labor share is statistically significant at $1 \%$ and mathematically relevant. Assuming everything else constant, a one pp increase in the labor share tended to raise consumer inflation by approximately $0.188 \mathrm{pp}$ in 1991-2019.

To corroborate the VEC result, we also estimated a single equation for the structuralist Phillips curve, defining the change in consumer inflation (the second derivative of the consumer price) as a function of its past changes and of the deviation of inflation from the long-run value determined by import-price inflation, the rate of unemployment, and the labor share. The univariate model also contains a pulse dummy for the $2008 \mathrm{crash}$, and its results are close to what we obtained from the multivariate model. The advantage of the univariate specification is that it allows us to measure how each factor contributes to explaining inflation in a more intuitive manner. Table 4 presents alternative specifications of the Structuralist Phillips curve. The estimates coefficients indicate that:

(i) A simple error-correction specification in which inflation converges to a fixed mean, with a dummy variable to control for the 2008 crash, explains $63 \%$ of the sample variance.

(ii) When we add the rate of unemployment to the model, the estimated coefficient is not statistically significant and the adjusted R-squared of the regression falls by $0.3 \%$. This result means that the Phillips curve did not work as expected in the last 30 years, another common result of the literature on the topic.

(iii) Introducing imported inflation improves the model's statistical fit, raising the R-squared to almost $65 \%$. The estimated coefficient import prices has the "correct sign", but its value is not statistically significant at $10 \%$.

(iv) Adding the labor share to the regression raises the R-squared to $67 \%$ and makes the coefficient for import-price inflation statistically significant at $5 \%$.

(v) More importantly, in the more general model, the coefficient for the labor share is statistically significant at $0.1 \%$, with a positive sign, while the coefficient for the rate of unemployment continues to be low, with the wrong sign, and not statistically different than zero. 
The US had no standard Phillips curve in 1991-2019, but it seems to have followed a Structuralist Phillips curve, in which inflation responds to the labor share, which in its turn responded to the rate of unemployment.

Table 4: Single equation estimation of the Structuralist Phillips curve for 1991Q1-2019Q4, change in consumer inflation is the dependent variable

\begin{tabular}{|c|c|c|c|c|c|c|c|c|}
\hline \multirow[t]{2}{*}{ Variable } & \multicolumn{4}{|c|}{$\begin{array}{l}\text { Model 1: simple error-correction with a } \\
\text { dummy for the } 2008 \text { crash }\end{array}$} & \multicolumn{4}{|c|}{ Model 2: with the rate of unemployment } \\
\hline & Coefficient & Std. Error & t-Statistic & Prob. & Coefficient & Std. Error & t-Statistic & Prob. \\
\hline C & 0.0113 & 0.0024 & 4.6294 & $0.0 \%$ & 0.0102 & 0.0037 & 2.7756 & $0.7 \%$ \\
\hline $\mathrm{D}\left(4 * \mathrm{DLOG}\left(\mathrm{P} \_\mathrm{PCE}(-1)\right)\right)$ & 0.0047 & 0.1190 & 0.0396 & $96.9 \%$ & 0.0030 & 0.1161 & 0.0259 & $97.9 \%$ \\
\hline $\mathrm{D}\left(4 * \mathrm{DLOG}\left(\mathrm{P} \_\mathrm{PCE}(-2)\right)\right)$ & -0.1124 & 0.0824 & -1.3628 & $17.6 \%$ & -0.1131 & 0.0809 & -1.3987 & $16.5 \%$ \\
\hline 4*DLOG(P_PCE(-1)) & -0.5739 & 0.1176 & -4.8803 & $0.0 \%$ & -0.5720 & 0.1162 & -4.9218 & $0.0 \%$ \\
\hline D2008Q4 & -0.0885 & 0.0023 & -37.7265 & $0.0 \%$ & -0.0885 & 0.0023 & -37.7423 & $0.0 \%$ \\
\hline U_RATE_SA(-1)/100 & & & & & 0.0172 & 0.0466 & 0.3698 & $71.2 \%$ \\
\hline \multicolumn{9}{|l|}{ 4*DLOG(P_IMP(-1)) } \\
\hline \multicolumn{9}{|l|}{ LSNDI(-1) } \\
\hline R-squared & \multicolumn{4}{|c|}{0.63176} & \multicolumn{4}{|c|}{0.63206} \\
\hline Adjusted R-squared & \multicolumn{4}{|c|}{0.61849} & \multicolumn{4}{|c|}{0.61533} \\
\hline Durbin-Watson stat & \multicolumn{4}{|c|}{2.08820} & \multicolumn{4}{|c|}{2.09054} \\
\hline F-statistic & \multicolumn{4}{|c|}{47.60858} & \multicolumn{4}{|c|}{33.62050} \\
\hline Prob(F-statistic) & \multicolumn{4}{|c|}{0.00000} & \multicolumn{4}{|c|}{0.00000} \\
\hline \multirow[t]{2}{*}{ Variable } & \multicolumn{4}{|c|}{$\begin{array}{l}\text { Model 3: with the rate of unemployment } \\
\text { and import-price inflation }\end{array}$} & \multicolumn{4}{|c|}{$\begin{array}{l}\text { Model 4: with the rate of unemployment, } \\
\text { import-price inflation, and the labor share }\end{array}$} \\
\hline & Coefficient & Std. Error & t-Statistic & Prob. & Coefficient & Std. Error & t-Statistic & Prob. \\
\hline C & 0.01524 & 0.00518 & 2.94408 & $0.4 \%$ & -0.08675 & 0.03104 & -2.79484 & $0.6 \%$ \\
\hline $\mathrm{D}\left(4^{*} \mathrm{DLOG}\left(\mathrm{P} \_\mathrm{PCE}(-1)\right)\right)$ & -0.01961 & 0.11810 & -0.16607 & $86.8 \%$ & 0.02357 & 0.10267 & 0.22959 & $81.9 \%$ \\
\hline $\mathrm{D}\left(4 * \mathrm{DLOG}\left(\mathrm{P} \_P C E(-2)\right)\right)$ & -0.17921 & 0.09487 & -1.88901 & $6.2 \%$ & -0.16761 & 0.08364 & -2.00393 & $4.8 \%$ \\
\hline 4*DLOG(P_PCE(-1)) & -0.82279 & 0.17919 & -4.59183 & $0.0 \%$ & -0.97966 & 0.15152 & -6.46559 & $0.0 \%$ \\
\hline D2008Q4 & -0.08699 & 0.00233 & -37.28368 & $0.0 \%$ & -0.08749 & 0.00189 & -46.19666 & $0.0 \%$ \\
\hline U_RATE_SA(-1)/100 & 0.00785 & 0.05163 & 0.15205 & $87.9 \%$ & 0.00752 & 0.04985 & 0.15081 & $88.0 \%$ \\
\hline 4*DLOG(P_IMP(-1)) & 0.05415 & 0.03346 & 1.61866 & $10.8 \%$ & 0.07237 & 0.03089 & 2.34258 & $2.1 \%$ \\
\hline LSNDI(-1) & & & & & 0.16258 & 0.04942 & 3.28977 & $0.1 \%$ \\
\hline R-squared & \multicolumn{4}{|c|}{0.64921} & \multicolumn{4}{|c|}{0.67547} \\
\hline Adjusted R-squared & \multicolumn{4}{|c|}{0.62990} & \multicolumn{4}{|c|}{0.65444} \\
\hline Durbin-Watson stat & \multicolumn{4}{|c|}{2.01408} & \multicolumn{4}{|c|}{2.07004} \\
\hline F-statistic & \multicolumn{4}{|c|}{33.62050} & \multicolumn{4}{|c|}{32.11328} \\
\hline Prob(F-statistic) & \multicolumn{4}{|c|}{0.00000} & \multicolumn{4}{|c|}{0.00000} \\
\hline
\end{tabular}

Source: authors' calculation

Figure 13 shows the actual, fitted, and residual series of the single-equation Structuralist model. Considering the long-run relationship implicit in table 4, we have:

$\pi_{C}=-0.089+0.074 \pi_{M}+0.008 u+0.166 l$. 
In words, the single-equation coefficient for the labor share $(0.166)$ is close to what we obtained from the multivariate VEC model (0.188), confirming that a one pp increase in in the workers' share of net domestic income tended to push US inflation up in approximately $0.2 \mathrm{pp}$ in the last 30 years.

Figure 13: Actual and fitted consumer inflation from the estimated Structuralist Phillips curve (model 4 of table 4) for 1991Q1-2019Q4

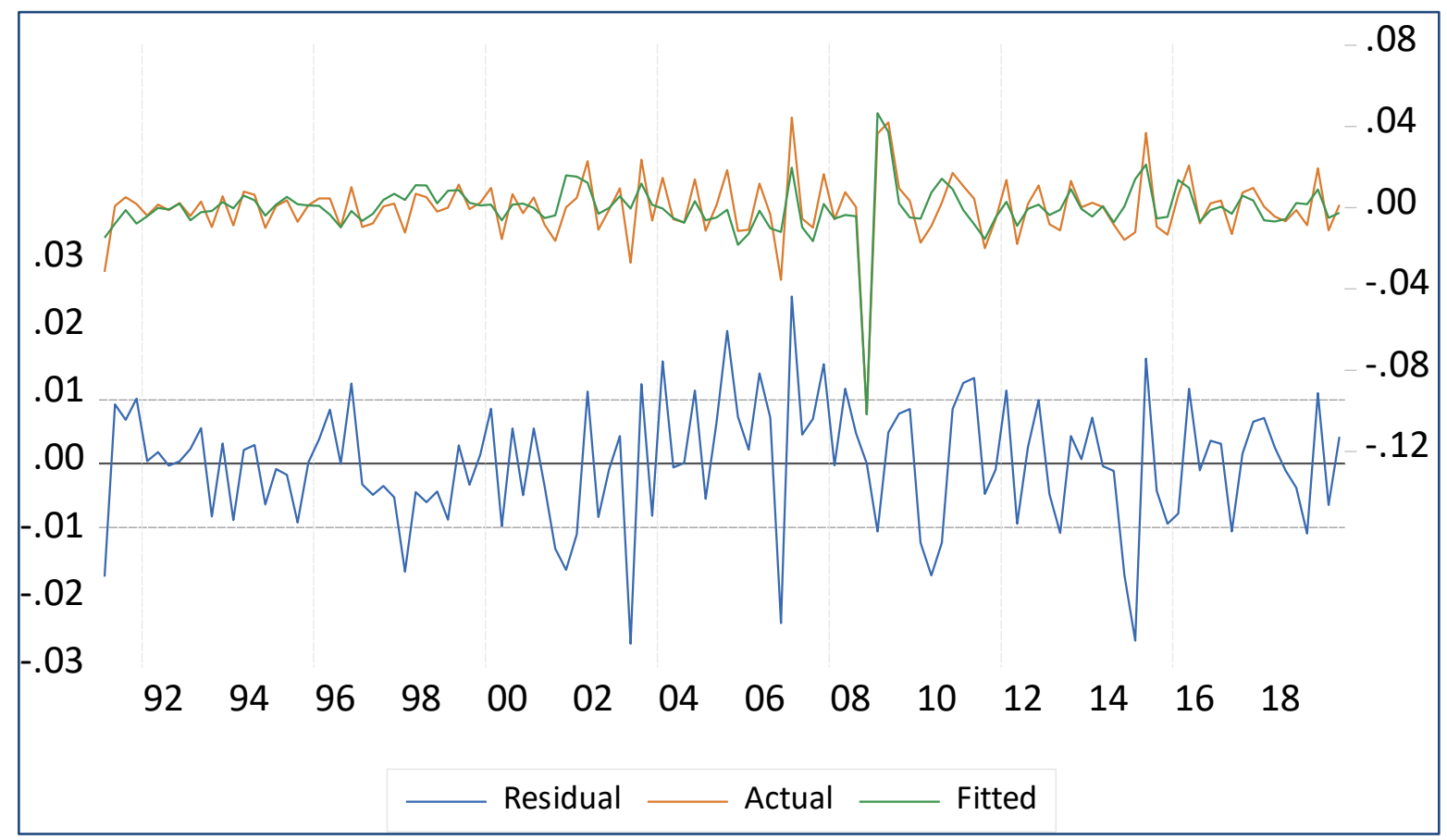

Source: authors' estimate. 


\section{References}

Anderson, Gary S. (2008): "Solving Linear Rational Expectations Models: A Horse Race", Computational Economics: 31, 95-113.

Barbosa-Fiho, Nelson H. (2014) “A Structuralist Inflation Curve," Metroeconomica, 65-2: 349376.

Barbosa-Filho, Nelson H., and Lance Taylor (2006) "Distributive and Demand Cycles in the U.S. Economy - A Structuralist Goodwin Model, Metroeconomica, 57: 389-411.

Carlin, Wendy and David Soskice (2005): “The 3-equation New Keynesian model - A graphical exposition", Contributions to Macroeconomics: 5(1): 13.

Dickens, Edwin (2016) The Political Economy of U.S. Monetary Policy, London and New York: Routledge.

Friedman, Milton (1968) “The Role of Monetary Policy,” American Economic Review, 58: 1-17. Goodwin, Richard M. (1967) “A Growth Cycle,” in C. H. Feinstein (ed.) Socialism, Capitalism, and Growth, Cambridge UK: Cambridge University Press.

Gordon, Robert J. (2011): "The History of the Phillips Curve: Consensus and Bifurcation", Economica: $78,10-50$.

Hossenfelder, Sabine (2018) Lost in Math, New York: Basic Books.

Lucas, Robert E, Jr. (1972) "Expectations and the Neutrality of Money," Journal of Economic Theory, 4: 103-124.

Peters, Ole (2019) “The Ergodicity Problem in Economics," Nature Physics. 15: 1216-1221 (2019). https://doi.org/10.1038/s41567-019-0732-0

Phelps, Edmund S. (1968) “Money-Wage Dynamics and Market Equilibrium,” Journal of Political Economy, 76: 678-711.

Phillips, William (1958), “The Relationship Between Unemployment and the the Rate of Change of Money Wage Rates in the United Kingdom 1861-1957,” Economica Nov., 283-99.

Samuelson, Paul A., and Robert M. Solow (1960) "Analytical Aspects of Anti-Inflation Policy," American Economic Review (Papers and Proceedings), 50(2): 177-194.

Taylor, Lance (2004) Reconstructing Macroeconomics: Structuralist Proposals and Critiques of the Mainstream, Cambridge MA: Harvard University Press.

Taylor, Lance (2020) "Germany and China have Saving Gluts, The USA is a Sump: So What? https://www.ineteconomics.org/research/research-papers/germany-and-china-have-savings-glutsthe-usa-is-a-sump-so-what 
Taylor, Lance, with Özlem Ömer (2020) Macroeconomic Inequality from Reagan go Trump: Market Power, Wage Repression, Price Inflation, and Industrial Decline, New York: Cambridge University Press.

Woodford, Michael (2003): Interest and Prices: Foundations of a Theory of Monetary Policy, Princeton: Princeton University Press. 